\title{
60. SILICOFLAGELLATE AND COCCOLITH STRATIGRAPHY, SOUTHEASTERN PACIFIC OCEAN, DEEP SEA DRILLING PROJECT LEG 34
}

\author{
David Bukry, United States Geological Survey, La Jolla, California
}

\section{INTRODUCTION}

Leg 34 of the Deep Sea Drilling Project, December 1973 to February 1974, which began at Papeete, Tahiti, and ended at Callao, Peru (Figure 1), recovered 44 cores at three drilling sites, Sites 319-321. Light-microscope techniques were used to study the coccoliths and silicoflagellates of 89 samples. Coccolith zonation, based on Bukry (1973, 1975a), and silicoflagellate zonation, based on Bukry and Foster (1973), are summarized (Figures 2 and 3). Relative abundances of silicoflagellate taxa at Sites 320 and 321 are recorded as percent of total specimens (Figures 4 and 5). Stratigraphic and paleoecologic aspects of the phytoplankton assemblages are discussed, along with a special glossary of the descriptive terminology of silicoflagellates defined here to provide standardized terms for analogous elements. Two new silicoflagellate subspecies of Dictyocha are described, Dictyocha perlaevis delicata n. sub$\mathrm{sp}$. and Dictyocha stapedia aspinosa n. subsp.

\section{SITE SUMMARIES}

\section{Site 319}

\section{(lat $13^{\circ} 01.04^{\prime} \mathrm{S}$, long $101^{\circ} 31.46^{\prime} \mathrm{W}$, depth $4296 \mathrm{~m}$ )}

Site 319 was drilled to investigate the geologic history of metalliferous sedimentation on the Nazca tectonic plate, west of South America. The youngest fossil assemblages from Core 1, Sections 4 and 5 ( 6 to $9 \mathrm{~m}$ ), are assigned to the late Miocene Ceratolithus primus Subzone of the Discoaster quinqueramus Zone on the basis of abundant coccoliths including such species as: Ceratolithus amplificus, C. primus, C. tricorniculatus, Discoaster brouweri, D. pentaradiatus, D. quinqueramus, $D$. surculus, $D$. variabilis, and Triquetrorhabdulus rugosus. Specimens of Ceratolithus are especially common in Section 4 at $50-52 \mathrm{~cm}$. Coccolith assemblages from the top of Core $2(10$ to $14 \mathrm{~m})$ are poorly diagnostic. The rare occurrence of Discoaster loeblichii in Section 3 and the rare occurrence of $D$. berggrenii in Section 1 permits the assignment to subzones (Figure 2). A co-occurrence of Discoaster bellus and D. pentaradiatus with common Minylitha convallis indicates the Discoaster neohamatus Zone in Core 3 (19 to $29 \mathrm{~m}$ ).

Core 4 (29 to $38 \mathrm{~m})$ is described by shipboard sedimentologists as intensely marbled. Coccolith assemblages show younger Discoaster hamatus Zone sediment in Section 2 at 50-52 cm lying beneath older Catinaster coalitus Zone sediment in Section 1 at 50-52 $\mathrm{cm}$. Rare specimens of Discoaster kugleri occur in Sections 1 and 6 . Although specific samples show nonsequential zonation, all three late middle Miocene coccolith zones are represented in Core 4.
The changes in coccolith assemblages through the thick Sphenolithus heteromorphus Zone of Cores 5 to 12 (38 to $112 \mathrm{~m}$ ) suggest a complete representation of the zone. Species dwindling upwards through the interval include Cyclicargolithus floridanus, Discoaster deflandrei, and Sphenolithus heteromorphus. Those first appearing or increasing upwards through the interval include Cyclococcolithina macintyrei, Discoaster exilis, Sphenolithus neoabies, and Triquetrorhabdulus rugosus. In contrast with other regions, $T$. rugosus is especially persistent and common through all of the Miocene samples.

\section{Site 320}

(lat $9^{\circ} 00.40^{\prime} \mathrm{S}$, long $83^{\circ} 31.80^{\prime} \mathrm{W}$, depth $4487 \mathrm{~m}$ )

Site 320 near the eastern margin of the Nazca plate about $350 \mathrm{~km}$ west of Peru was drilled principally to sample basement; the overlying sediment section was only partly cored.

Two shallow Cores 1 and $1 \mathrm{~A}$ ( 0 to $16 \mathrm{~m}$ ) recovered late Quaternary sediment rich in silicoflagellates and diatoms, but barren of coccoliths. Not only have the calcareous phytoplankton been dissolved, but also the siliceous specimens that have been preserved are noticeably thinned and weakened as a result of solution. Silicoflagellate assemblages, dominated by Dictyocha stapedia stapedia, are assigned to the Dictyocha epiodon Zone of late Quaternary to Holocene age. A high Dictyocha/Distephanus ratio for the species array is comparable to but higher than those at Site 157 , some $8^{\circ}$ to the north nearer the Equator because of fewer specimens of cool-water Distephanus. Site 157 is and probably was more directly under the influence of the Humboldt Current, which diverges westward from the South American continental margin just south of the Equator.

Diatoms present in the two shallow cores at Site 320 also suggest warm-water conditions. The occurrence of the tropical guide species Pseudoeunotia doliolus in all samples examined permits assignment of the cores to the zone of the same name. Cool-water species such as Coscinodiscus curvatulus and C. marginatus are missing. Thalassiothrix longissima is the most abundant species in the section. Other diatoms present include: Actinoptychus sp. cf. A. vulgare monicae, A. senarius, Asterolampra decora, Asteromphalus brookei, A. imbricatus (most abundant near top of the section, as at Site 157), Coscinodiscus africanus, $C$. asteromphalus, C. excentricus, $C$. lineatus, $C$. nodulifer, Ethmodiscus rex, Hemidiscus cuneiformis, Melosira sulcata, Nitzschia spp., Rhizosolenia bergonii, $R$. styliformis, Roperia tesselata, Stephanopyxis turris, Thalassionema nitzschioides, Thalassiosira oestrupii (girdles predominate), and Triceratium cinnamomeum. 


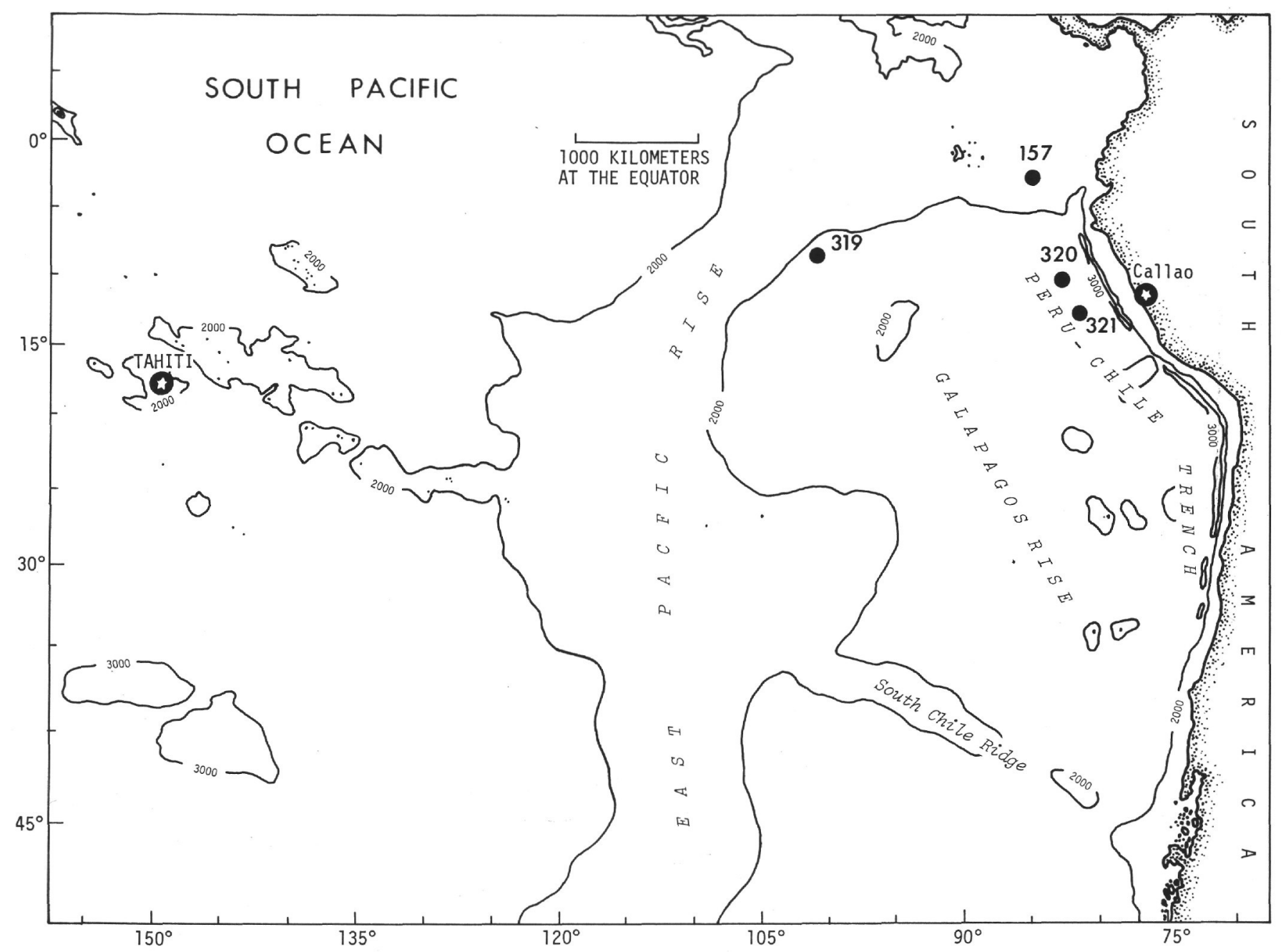

Figure 1. Location of Deep Sea Drilling Project Leg 34 sites and Site 157, drilled on Leg 16. Submarine contours in fathoms.

Deeper Cores 2 to 3 ( 74 to $112 \mathrm{~m}$ ) and $1 \mathrm{~B}$ to $2 \mathrm{~B}$ (136 to $155 \mathrm{~m}$ ) contain early Miocene and late Oligocene coccolith assemblages and lack silicoflagellates and diatoms. The common occurrence of Coccolithus sp. cf. C. fenestratus, Cyclicargolithus abisectus, and Triquetrorhabdulus carinatus in Core 2B, Sections 3 and 5, suggests the lower part of the Triquetrorhabdulus carinatus Zone (Cyclicargolithus abisectus Subzone). Of the three species cited, only $C$. abisectus is prominent in higher Core 3 (102 to $112 \mathrm{~m}$ ), where the most prominent species are Cyclicargolithus floridanus, Discoaster deflandrei, and Sphenolithus dissimilis, suggesting assignment either to the upper $C$. abisectus Subzone or to the Discoaster deflandrei Subzone. The absence of any specimens of the older late Oligocene guide species Dictyococcites bisectus and Sphenolithus ciperoensis indicates that the basal sediment is latest Oligocene, less than 24 million years old. Abundant sphenoliths suggest warm-water conditions, and the few specimens of Discolithina and Helicopontosphaera indicate deposition well above the calcite compensation depth.

Samples from the upper part of Core 2 (74 to $77 \mathrm{~m}$ ) contain coccolith assemblages very similar to and only slightly older than the basal assemblage at Site 319 . The occurrence of common Cyclicargolithus floridanus, Discoaster deflandrei, and Sphenolithus heteromorphus, and meager Discoaster exilis, without Cyclococcolithina macintyrei, indicate the upper part of the Helicopontosphaera ampliaperta Zone.

\section{Site 321}

(lat $12^{\circ} 01.29^{\prime} \mathrm{S}$, long $81^{\circ} 54.24^{\prime} \mathrm{W}$, depth $4827 \mathrm{~m}$ )

Site 321 was continuously cored to obtain a complete section from an older portion of the eastern Nazca plate than Site 320 to the north. The upper section, recovered in Cores 1 to 4 ( 1 to $26 \mathrm{~m}$ ), contains abundant silicoflagellates and diatoms, but no coccoliths. The occurrence of low-latitude marker species for both groups of siliceous phytoplankton permits recognition of the tropical east Pacific zonal sequence from late Pliocene to late Quaternary. A lower fossiliferous section, Cores 8 to 13 (59 to $125 \mathrm{~m}$ ), contains abundant coccoliths ranging in age from late Eocene to late Oligocene. Cores 5 to 7 (30 to $59 \mathrm{~m}$ ) contain practically unfossiliferous clay and ash for which no phytoplankton-based micropaleontologic ages are assigned; see reports of shipboard scientists for possible radiolarian-based determinations. 
SILICOFLAGELLATE AND COCCOLITH STRATIGRAPHY

\begin{tabular}{|c|c|c|c|c|c|}
\hline Age & Zone & Subzone & 319 & 320 & 321 \\
\hline \multirow{5}{*}{ 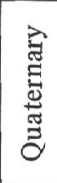 } & \multicolumn{2}{|l|}{ Emiliania huxleyi } & & & \\
\hline & \multirow{2}{*}{$\begin{array}{l}\text { Gephyrocapsa } \\
\text { oceanica }\end{array}$} & Ceratolithus cristatus & & & \\
\hline & & Emiliania ovata & & & \\
\hline & \multirow{2}{*}{$\begin{array}{l}\text { Crenalithus } \\
\text { doronicoides }\end{array}$} & Gephyrocapsa caribbeanica & & & \\
\hline & & Emiliania annula & & & \\
\hline \multirow{8}{*}{ 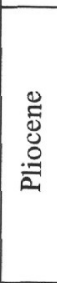 } & \multirow{4}{*}{$\begin{array}{r}\text { Discoaster } \\
\text { brouweri }\end{array}$} & Cyclococcolithina macintyrei & & & \\
\hline & & Discoaster pentaradiatus & & & \\
\hline & & Discoaster surculus & & & \\
\hline & & Discoaster tamalis & & & \\
\hline & \multirow{2}{*}{$\begin{array}{l}\text { Reticulofenestra } \\
\text { pseudoumbilica }\end{array}$} & Discoaster asymmetricus & & & \\
\hline & & Sphenolithus neoabies & & & \\
\hline & \multirow{3}{*}{$\begin{array}{l}\text { Ceratolithus } \\
\text { tricorniculatus }\end{array}$} & Ceratolithus rugosus & & & \\
\hline & & Ceratolithus acutus & & & \\
\hline \multirow{15}{*}{ 离 } & & Triquetrorhabdulus rugosus & & & \\
\hline & \multirow{2}{*}{$\begin{array}{l}\text { Discoaster } \\
\text { quinqueramus }\end{array}$} & Ceratolithus primus & $1-4 / 1-5$ & & \\
\hline & & Discoaster berggrenii & $? 2-1$ & & \\
\hline & \multirow{2}{*}{$\begin{array}{l}\text { Discoaster } \\
\text { neohamatus }\end{array}$} & Discoaster neorectus & $2-2 / 2-3$ & & \\
\hline & & Discoaster bellus & $3-2 / 3-3$ & & \\
\hline & \multirow{2}{*}{$\begin{array}{l}\text { Discoaster } \\
\text { hamatus }\end{array}$} & Catinaster calyculus & & & \\
\hline & & Helicopontosphaera kamptneri & $4-2$ & & \\
\hline & \multicolumn{2}{|l|}{ Catinaster coalitus } & $4-1 \& 4-3$ & & \\
\hline & \multirow{2}{*}{$\begin{array}{l}\text { Discoaster } \\
\text { exilis }\end{array}$} & Discoaster kugleri & & & \\
\hline & & Coccolithus miopelagicus & $4-4 / 4-5$ & & \\
\hline & \multicolumn{2}{|c|}{ Sphenolithus heteromorphus } & $5-2 / 12-3$ & & \\
\hline & \multicolumn{2}{|c|}{ Helicopontosphaera ampliaperta } & & $2-1 / 2-2$ & \\
\hline & \multicolumn{2}{|c|}{ Sphenolithus belemnos } & & & \\
\hline & \multirow{3}{*}{$\begin{array}{l}\text { Triquetrorhabdulus } \\
\text { carinatus }\end{array}$} & Discoaster druggii & & & \\
\hline & & Discoaster deflandrei & & & \\
\hline & & Cyclicargolithus abisectus & & $3-1 / 2 B-5$ & \\
\hline & Sphenolithus & Dictyococcites bisectus & & & \\
\hline 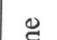 & ciperoensis & Cyclicargolithus floridanus & & & $8-1 / 9-1$ \\
\hline ల్ల్ & Sphenolithus distent & & & & $9-2 / 10-3$ \\
\hline$\stackrel{0}{=0}$ & Sphenolithus predist & tus & & & $11-1 / 11-3$ \\
\hline$\overline{0}$ & & Reticulofenestra hillae & & & $? 11-4$ \\
\hline & Helicoponiospnaera & Coccolithus formosus & & & \\
\hline & & Coccolithus subdistichus & & & \\
\hline & Discoaster & Isthmolithus recurvus & & & \\
\hline & barbadiensis & Chiasmolithus oamaruensis & & & $13-1 / 13-2$ \\
\hline & Reticulofenestra & Discoaster saipanensis & & & \\
\hline & umbilica & Discoaster bifax & & & \\
\hline & & Coccolithus staurion & & & \\
\hline & Nannotetrina & Chiasmolithus gigas & & & \\
\hline $\bar{\delta}$ & & Discoaster strictus & & & \\
\hline i- & Discoaster & Rhabdosphaera inflata & & & \\
\hline & sublodoensis & Discoasteroides kuepperi & & & \\
\hline & Discoaster lodoensis & & & & \\
\hline & Tribrachiatus orthos & & & & \\
\hline & Discoaster & Discoaster binodosus & & & \\
\hline & diastypus & Tribrachiatus contortus & & & \\
\hline & Discoaster & Campylosphaera eodela & & & \\
\hline & multiradiatus & Chiasmolithus bidens & & & \\
\hline$\stackrel{\mathscr{E}}{0}$ & Discoaster nobilis & & & & \\
\hline$\ddot{\circlearrowright}$ & Discoaster mohleri & & & & \\
\hline$\frac{0}{\pi}$ & Heliolithus kleinpell & & & & \\
\hline & Fasciculithus tympar & ormis & & & \\
\hline & Cruciplacolithus tent & & & & \\
\hline
\end{tabular}

Figure 2. Coccolith zonation of core samples from DSDP Leg 34. If more than one sample is assigned to a zonal unit, only the highest and lowest are listed, separated by a slash. A lettered core is from a supplemental drill hole.

Siliceous microfossil assemblages are similar to those at Site 157 to the north. Late Pliocene silicoflagellate assemblages of Core 4 ( 21 to $30 \mathrm{~m})$ are characterized by the consistent occurrence of Distephanus boliviensis boliviensis and $D$. speculum speculum. An abrupt reduction in the abundance of these two species and the equally abrupt appearance, in great abundance, of Mesocena elliptica directly above in Core 3 (11 to $21 \mathrm{~m}$ ) suggests a 


\begin{tabular}{|c|c|c|c|c|}
\hline \multirow{2}{*}{ Age } & \multirow{2}{*}{ Silicoflagellate Zone } & \multirow{2}{*}{ Diatom Zone } & \multicolumn{2}{|c|}{ SITE } \\
\hline & & & 320 & 327 \\
\hline \multirow{2}{*}{ 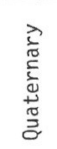 } & Dietyocha epiodon & \multirow{2}{*}{$\begin{array}{l}\text { Pseudoeunotia } \\
\text { doliolus }\end{array}$} & $\begin{array}{c}1 A-1 / 7 A-6 \\
8 \\
1-0 / 7-5\end{array}$ & $2-1 / 2-2$ \\
\hline & Mesocena elliptica & & & $2-3 / 3-6$ \\
\hline 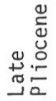 & $\begin{array}{l}\text { Distephanus } \\
\text { boliviensis } \\
\text { boliviensis }\end{array}$ & $\begin{array}{l}\text { Rhizosolenia } \\
\text { praebergonii }\end{array}$ & & $4-1 / 4-4$ \\
\hline
\end{tabular}

Figure 3. Silicoflagellate and diatom zonation of core sections from DSDP Leg 34. Diatom zonation is based on Burckle (1972).

hiatus in the sequence that could be real or the result of intense disruption of sediment layers by drilling. Dictyocha epiodon, indicating the late Quaternary, occurs only in the upper part of Core 2.

Diatoms present in Core 4 include the guide species Nitzschialjouseae, Rhizosolenia praebergonii, and Thalassiosira convexa that indicate the tropical late Pliocene Rhizosolenia praebergonii Zone of Burckle (1972). Other diatoms present include Actinocyclus ehrenbergii, Actinoptychus senarius, Asteromphalus brookei, A. imbricatus, Coscinodiscus asteromphalus, $C$. curvatulus, $C$. excentricus, $C$. lineatus, $C$. nodulifer, Ethmodiscus rex, Hemidiscus cuneiformis, Nitzschia marina, $N$. spp., Roperia sp. cf. $R$. tesselata, Thalassionema nitzschioides, Thalassiothrix longissima.

The ebridians Ammodochium rectangulare, Ebriopsis antiqua, and Paranthium tenuipes, which are generally not found above the Pliocene, occur in the Core 4 samples. Pseudoeunotia doliolus, a diatom marker species for the Quaternary, is common at the base of Core 3 but is less abundant in higher samples. A few specimens of Rhizosolenia curvirostris curvirostris, a cool-water diatom guide fossil for the Quaternary (Donohue, 1970), occur in Core 1, Section 1 (1 m). The majority of species present, however, indicate warmwater conditions. Diatom species present in Cores 1 to 3 include: Actinoptychus senarius, $A$. sp. cf. A. vulgare monicae, Asteromphalus brookei, $A$. imbricatus, $C$. asteromphalus, C. curvatulus, $C$. excentricus, $C$. lineatus, C. nodulifer, Denticula sp., Ethmodiscus rex, Hemidiscus cuneiformis, Nitzschia spp., Pseudoeunotia doliolus, Rhizosolenia bergonii, $R$. curvirostris curvirostris, $R$. curvirostris inermis, $R$. styliformis, Thalassionema nitzschioides, Thalassiosira oestrupii, Thalassiothrix longissima, Triceratium cinnamomeum. Strong dissolution and fragmentation of specimens is common.

The deepest sample available $(321-13-3,38-40 \mathrm{~cm} ; 119$ $\mathrm{m})$ from the basal ferruginous coccolith ooze section contains an etched late Eocene tropical assemblage with abundant discoasters and sphenoliths. Especially abundant species include Coccolithus formosus, Dictyococcites bisectus, Discoaster barbadiensis, D. saipanensis, $D$. tanii, Sphenolithus moriformis, and S. pseudoradians. Also present, but in smaller numbers, are Bramletteius serraculoides, Coccolithus pelagicus, Coronocyclus sp., Cyclicargolithus floridanus, Dictyococcites scrippsae, Discoaster nodifer, Pontosphaera vadosa, Reticulofenestra umbilica (rare), Sphenolithus sp. aff. $S$. conicus, and $S$. sp. cf. S. predistentus. Many coccolith species that are prominent in late Eocene cool-water assemblages, such as Chiasmolithus altus, C. oamaruensis, Corannulus germanicus, and Isthmolithus recurvus, are absent.

Tropical assemblages, that permit application of Sphenolithus biostratigraphy (Bramlette and Wilcoxon, 1967), persist through the section to the late Oligocene at the top of Core 8 .

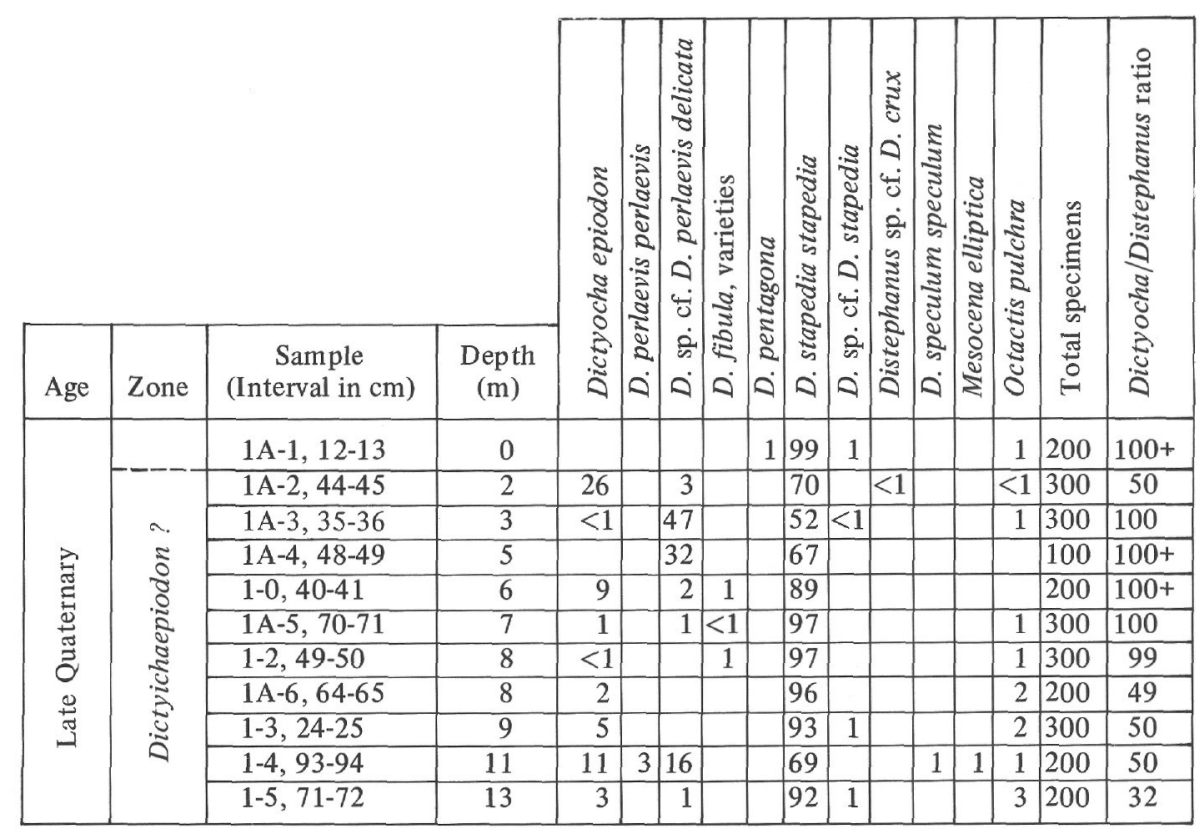

Figure 4. Occurrence of silicoflagellates in Cores 1 and $1 \mathrm{~A}$ at Site 320, recorded as percent of total specimens. The Dictyocha/Distephanus ratio suggests relative paleotemperature levels. Larger ratios reflect higher paleotemperatures (Mandra, 1969). 


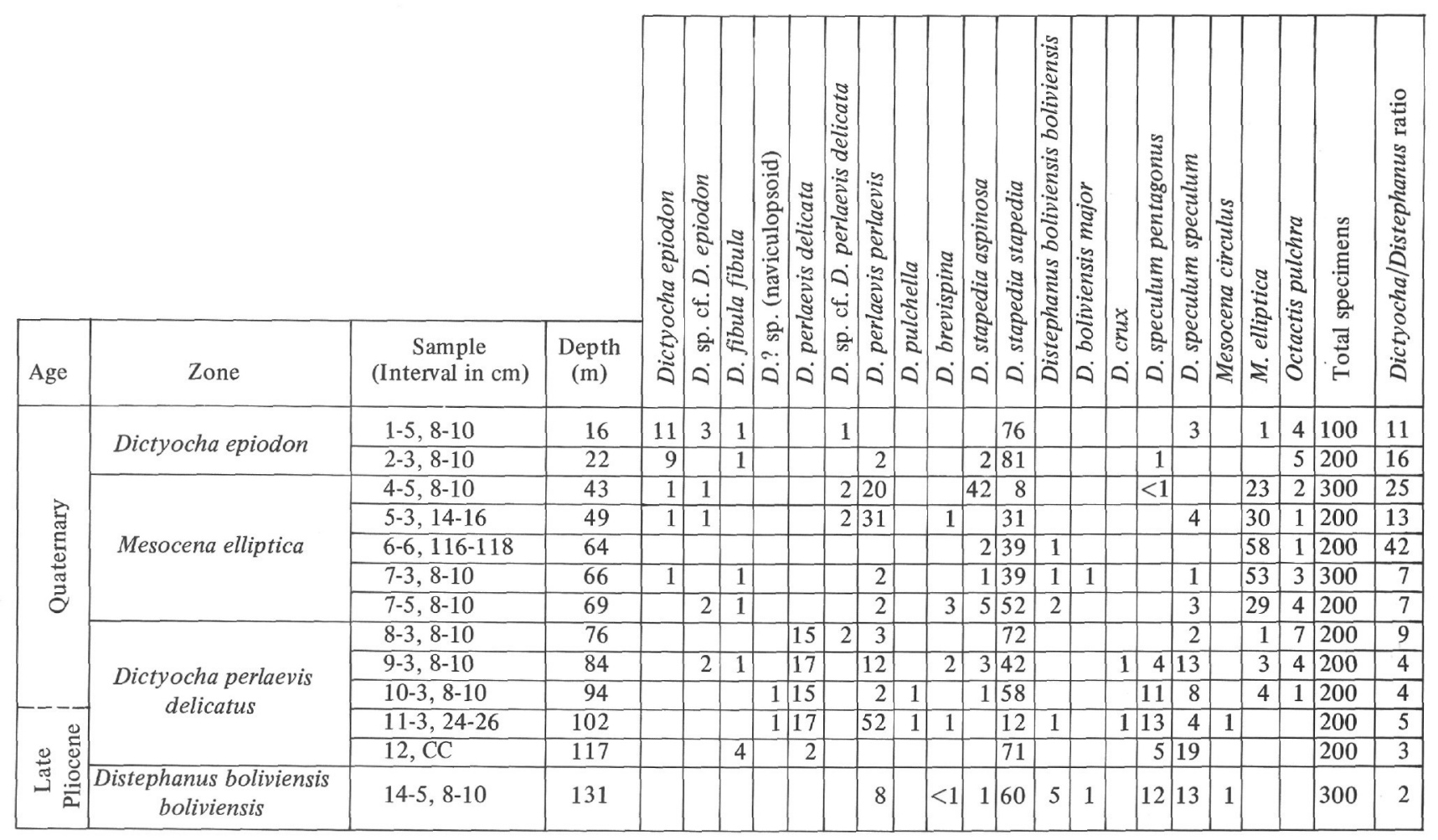

Figure 5. Occurence of silicoflagellates in Cores 1 to 4 at Site 321, recorded as percent of total specimens.

\section{SILICOFLAGELLATES}

\section{Stratigraphy}

Only the upper Pliocene to upper Quaternary portion of the low-latitude silicoflagellate zonal succession was recovered by the coring of DSDP Leg 34 . The lowlatitude silicoflagellate zones (Martini, 1971; Bukry and Foster, 1973) are readily identified, and no distinctly cold-water taxa, such as Dictyocha subarctios or Distephanus octangulatus, are present.

For purposes of correlation, some coeval samples from silicoflagellate-rich cores at Site 157 were newly examined for this report. A previously unrecorded stratigraphic assemblage may exist between the Distephanus boliviensis boliviensis Zone and the Mesocena elliptica Zone at Site 157. It is indicated as a new local zone named the Dictyocha perlaevis delicata Zone. Although the guide fossil Dictyocha perlaevis delicata is common at Site 321, the assemblage of the Dictyocha perlaevis delicata Zone has not been definitely recognized because Mesocena elliptica-dominated assemblages of Core 3 lie directly above those characterized by common Distephanus boliviensis boliviensis in Core 4 (Figure 5). At Site 157, D. perlaevis delicata is common in an extensive stratigraphic interval (approx. $40 \mathrm{~m}$ ) where both $M$. elliptica and $D$. boliviensis boliviensis are sporadic. This relation showing intraregional variation in stratigraphic sequences of silicoflagellates contrasts markedly with the less variable calcareous phytoplankton and emphasizes the great potential of siliceous phytoplankton for paleoecologic interpretations.

\section{Paleoecology}

Although the true precision of the temperature scale based on the Dictyocha/Distephanus ratio has yet to be determined (Mandra and Mandra, 1972), the generally warm levels indicated at Sites 157, 320, and 321 seem reasonable for low-latitude assemblages. Temperature and nutrient fluctuations that alter the species composition of assemblages through time are averaged together in samples that reflect different time durations because of differing rates of sediment accumulation and preservation at the sites. The fossil assemblage of a single sample represents the accumulation of many years. For example, the approximate time represented in a standard DSDP silicoflagellate sample (encompassing $2.3 \mathrm{~cm}$ of stratigraphic section) from the Quaternary sections at the three sites is 440 years for Site 157, 1240 years for Site 320, and 2170 years for Site 321. Therefore, the paleotemperature-indicating Dictyocha/Distephanus ratio for given samples represent averages over different time periods for different sites.

Recent work on silicoflagellate paleotemperatures (Jendrzejewski and Zarillo, 1971; Ciesielski and Weaver, 1974; Poelchau, 1974) suggest still other complexities in determining true paleotemperatures for various regions because of endemic species, varied productivity of different water masses, and differential grazing by predators. But the basic relation of Distephanusdominated assemblages in cold areas and Dictyocha in warm (Gemeinhardt, 1930) has been verified by DSDP drilling in the subarctic, tropical, and subantarctic Pacific Ocean. Relative abundance trends between these two genera (Figures 4-6) at east Pacific sites may repre- 


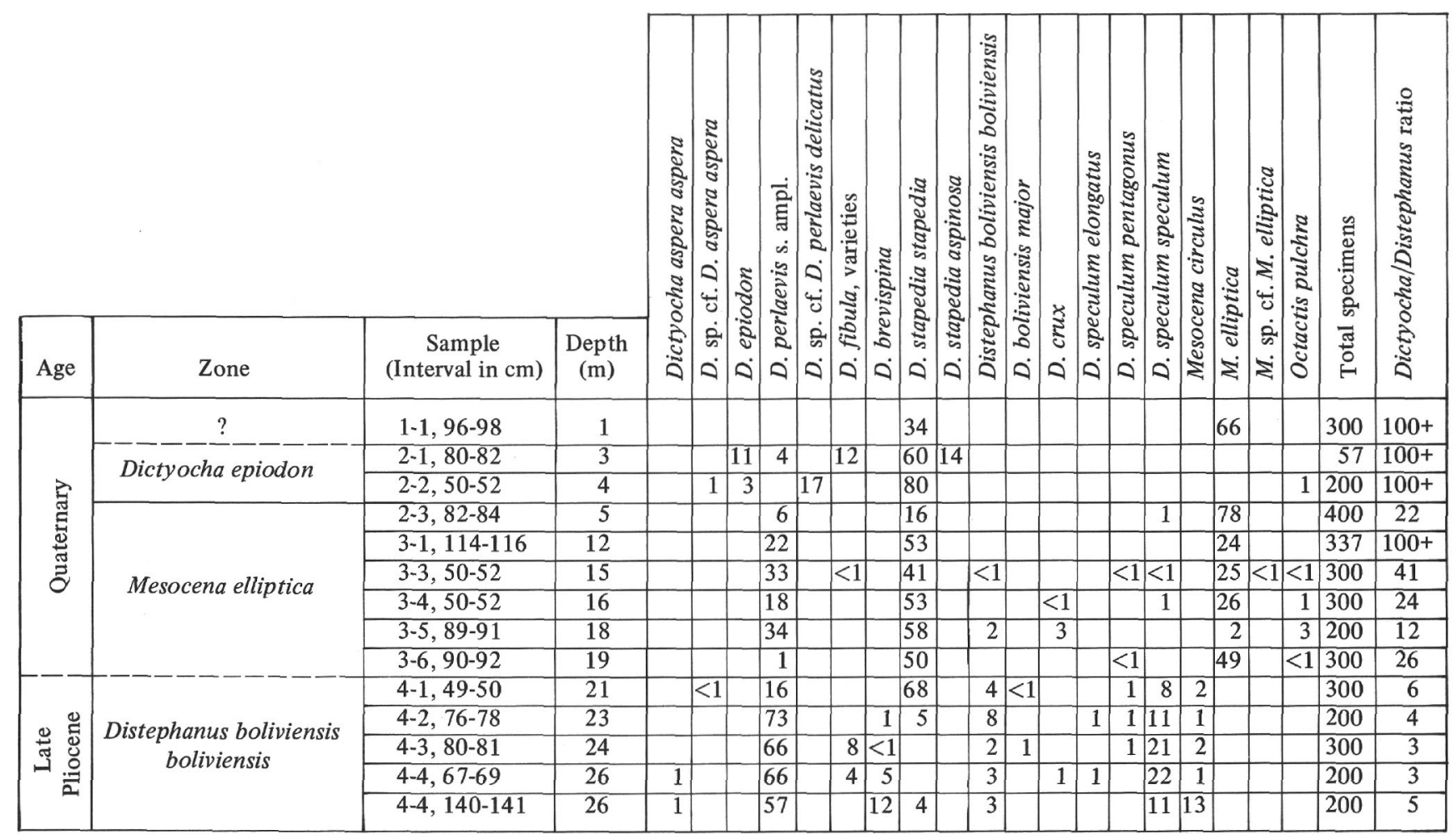

Figure 6. Occurrence of silicoflagellates in Cores 1 to 14 at Site 157 recorded as percent of total specimens.

sent true environmental alteration. The indicated change for oceanic areas west of Ecuador and Peru is a progressive warming for late Pliocene to late Quaternary. The cool-water indicator Distephanus occurs in significant numbers only in the Pliocene. In Quaternary assemblages that are dominated by the warm-water indicator Dictyocha, Distephanus is typically absent or less than $5 \%$. The smallest numbers of Distephanus are in the youngest silicoflagellate zone, the Dictyocha epiodon Zone, which is correlative with the Bruhnes magnetic epoch (approx. 0.0-0.7 m.y.). This trend suggests that the Quaternary large-scale air-water circulation pattern related to glaciation nearer the poles is associated with reduced upwelling at these sites off northern South America and therefore with warmer surface water than was true in the Pliocene.

\section{Glossary of Descriptive Terms}

The basic structural terms used to describe silicoflagellate skeletons in recent literature are from Deflandre (1950), Tynan (1957), Mandra (1968), and Ling (1972). The terminology presented here is an attempt to provide short standardized names for the structures in which analogous elements are identified by parallel terms (Figures 7 and 8).

Apical opening: Single or multiple circular or polygonal open area outlined within an apical ring.

Apical ring: Circular or polygonal ring and associated structures connected by struts to a basal ring which is larger. It is a primary structural element of the genera Distephanus and Octactis.

Apical view: Top view with apical structure toward the observer. band: Broad flat ribbon-like surface arching across the minor axis and connecting opposite sides of the basal ring. It is a typical structure of some species of Naviculopsis, such as $N$. constricta and $N$. foliacea. The plate of Corbisema geometrica, Dictyocha deflandrei, or Vallacerta hortonii differs because of the three- to five-sided symmetry of its outline.

Bar: The principal rod-shaped apical element. In the genus Dictyocha the bar is connected to the basal ring by intervening struts. The bar may be simple, as in Dictyocha perlaevis perlaevis, or surmounted by a spire, as in D. stapedia stapedia. In the genus Naviculopsis, a bar is a rod-shaped element bridging the basal ring across the minor axis.

Basal ring: Circular or polygonal ring usually connected by struts to a smaller apical ring. It is a primary structural element of most silicoflagellate genera. In genera lacking apical rings and struts, such as Mesocena, the term ring can be substituted for basal ring.

Basal view: Bottom view, with the plane of the basal ring oriented perpendicular to the line of sight and closer to the observer than the apical structure.

Bulb: A typically hollow almost spherical to cylindrical protuberance at corners of the basal ring of the genus Hannaites. It is inflated in appearance, larger in diameter than the connected tubes (Mandra, 1969; Bukry, 1975b). A rather coarse reticulate pattern marks the surface.

Crenulate: A surface texture of regularly spaced cycles of nodes stimulating plications that encompass the basal ring (see Corbisema inermis disymmetrica of Dumitrica, 1973b). 


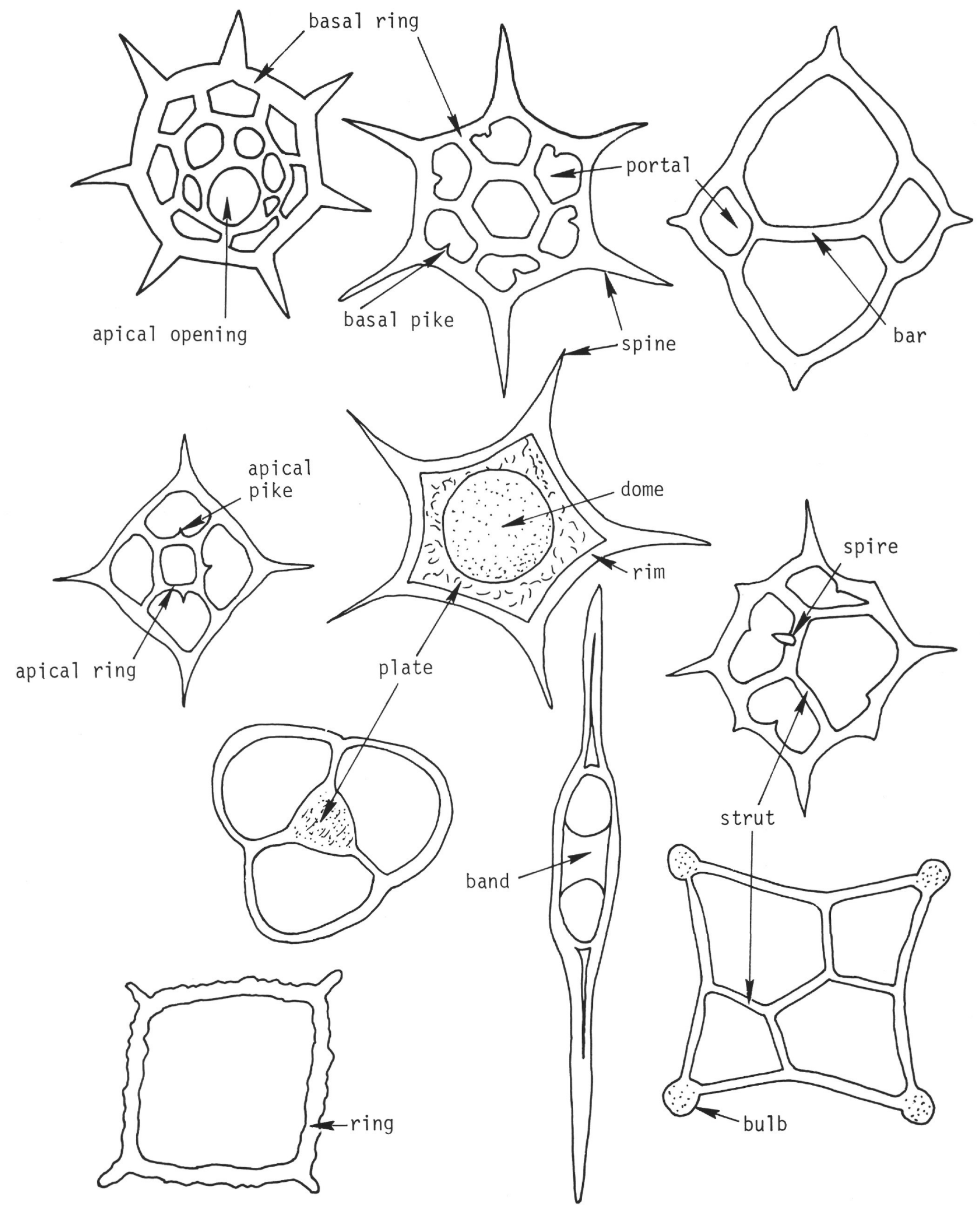

Figure 7. Terminology for principal structural elements used in description of silicoflagellate skeletons. 

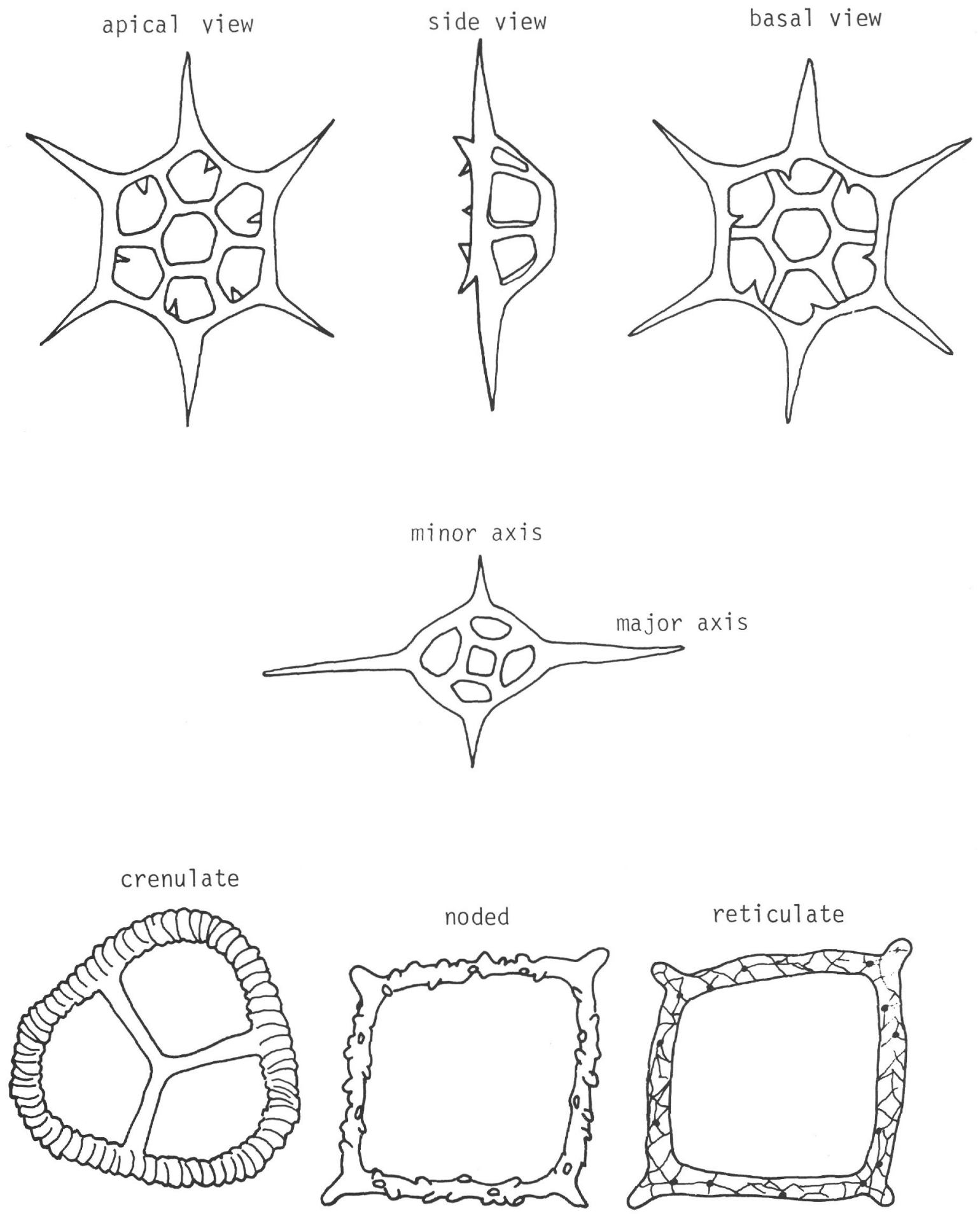

Figure 8. Terms used for orientation and surface texture of silicoflagellate specimens.

Dome: A raised hemispheric central portion of the plate in Vallacerta (see Glezer, 1966; Bukry, 1974).

Major axis: The direction of greatest length of bilaterally symmetric silicoflagellate skeletons. Generally applied to Dictyocha and Distephanus, but also applicable to some forms of Corbisema, Lyramula, Mesocena, Naviculopsis, and Octactis.

Minor axis: For bilaterally symmetric skeletons, the shortest distance through the center of symmetry in the plane of the basal ring.
Noded: A surface texture of irregular protuberances, smaller than pikes or spines, that is easily seen in light microscope. Typically, the texture is most prominent on rings of Mesocena and basal rings of Dictyocha. The individual protuberances, or nodes, may terminate bluntly, in points, or in irregular shapes. Their spacing suggests that they may be enlargements of line intersections in reticulate surface texture (see illustrations of Wornardt, 1971; and Dumitrica, 1973a). 
Pike: Short spine-like protrusion that has a smaller diameter and is usually shorter than a spine. Basal pikes on the basal ring are located directly beneath each strut or more commonly offset symmetrically clockwise or counterclockwise from the struts or spines. Apical pikes on the apical ring are typically midway between strut junctures. Synonymous published terms for basal pikes include: centripetal teeth (Haeckel, 1887), sustaining spines (Wornardt, 1971), and basal accessory spines (Ling, 1972).

Plate: An equant sheet-like apical structure that may be smooth or granular and is typically triangular in taxa such as Corbisema geometrica, and square in taxa such as Dictyocha deflandrei, both of which have struts connecting the plate to the basal ring. In Vallacerta the plate covers the entire interring area and arches slightly (McPherson and Ling, 1973).

Portal: Opening in a silicoflagellate skeleton that is bounded by the basal ring, struts, and apical ring or bar. The term is applicable to the genera Corbisema, Dictyocha, Distephanus, Hannaites, Naviculopsis, and Octactis. Genera such as Lyramula, Mesocena, or Vallacerta lack the structural elements needed to form portals. A synonymous term is lateral window (Ling, 1972).

Reticulate: A surface pattern of linear ridges meeting at small raised nodes is found on most silicoflagellates when examined by electron microscopy. This pattern is normally indistinct in light microscopy (see Mesocena polymorpha and Hannaites sp. on Plates 3 and 4). Excellent illustrations and discussions of this feature appear in Deflandre (1950), Bachmann and Keck (1969), Jerković (1969, 1971), Wornardt (1971), Dumitrica (1973a), and McPherson and Ling (1973). The electronmicrographs of Bachmann and Keck show areas with ridges where nodes are missing and areas where both are present on the same specimen. In addition, the illustrations of Wornardt show a difference in the size of nodes between two different species which suggests that the noded texture could be developed by enlargement of the reticulate texture. The other end member, wherein the reticulate pattern is missing, has been recorded in the unornamented plane surface of some specimems of Cannopilus from Mexico (Mandra and Mandra, 1972).

Rim: A peripheral structure of Vallacerta to which a plate is continuously attached. This structure is analogous to the basal ring of more openly constructed genera (see illustrations of McPherson and Ling, 1973).

Side View: View with the plane of the basal ring parallel to the line of sight. Side view illustrations are generally done with the major axis of the skeleton perpendicular to the line of sight. Lateral view is a synonymous term.

Spire: A pike on the bar structure of Dictyocha that rises perpendicular to the plane of the basal ring. Typically it is centrally located but may be offset to one end of the bar. A spire is distinguished from apical pikes or strut pikes by its orientation and isolated location.

Strut: Rod-shaped element that connects the apical ring, bar, or plate to the basal ring. It is an essential structure in the genera Corbisema, Dictyocha,Distephanus,
Hannaites, and Octactis. In Dictyocha medusa and certain species of Corbisema the struts meet simply and directly to form an apical structure without any special apical element such as a plate or bar.

\section{TAXONOMY}

\section{Genus DICTYOCHA Ehrenberg, 1837}

Dictyocha aspera aspera (Lemmermann)

Dictyocha fibula var. aspera Lemmermann, 1901, p. 260, pl. 10, fig. 27, 28.

Dictyocha cf. aspera Lemmermann, Dumitrica, 1973a (in part), p. 907, pl. 3, fig. 8; pl. 4, fig. 6 (not 5, 7, or 9); pl. 7, fig. 5 (not 4, 6, or 7).

Dictyocha aspera (Lemmermann) Bukry and Foster, 1973, p. 826, pl. 2, fig. 6 (not 4,5).

Remarks: Forms assigned to this taxon have the essential asperoid character of an apical bar transverse to the major axis of the basal ring or transverse to the major pair of spines in equant specimens. The corners of the basal ring are more angular than in similar asperoid taxa such as Dictyocha brevispina, D. pulchella, or the fibuloid taxon $D$. perlaevis perlaevis. Also the major and minor axes of the basal ring are nearly equal in contrast to more elongate forms such as $D$. brevispina and D. pulchella.

\section{Dictyocha brevispina (Lemmermann) n. comb.}

Dictyocha fibula var. brevispina Lemmermann, 1901, p. 260; Ehrenberg, 1854 (in part), pl. 21, fig. 42b; pl. 22, fig. 42a, b. Dictyocha fibula var. aspera f. rhombica Schulz, 1928, p. 253, fig. 37. Dictyocha ausonia Deflandre, 1950, p. 195, fig. 194-196, 199-202.

Dictyocha mutabilis Deflandre, 1950, p. 197, fig. 203-208, 210 (?209). Dictyocha mutabilis Deflandre, Tynan, 1957, p. 131, pl. 1, fig. 9.

Dictyocha rhombica (Schulz) Martini, 1971 (in part), p. 1698, pl. 1, fig. 9, 10.

Dictyocha fibula ssp. aspera Lemmermann, Dumitrica, 1973b (in part), p. 848 , pl. 2, fig. $10,12,13$.

Dictyocha fibula Ehrenberg, Dumitrica, 1973b (in part), p. 847, pl. 2, fig. 17 , pl. 3 , fig. $1-3$, pl. 5, fig. 1-4.

Dictyocha rhombica (Schulz), Bukry and Foster, 1974, p. 305, fig. 1k. Dictyocha rhombica (Schulz), Bukry, 1975a, pl. 4, fig. 5, 6.

Remarks: This generally large asperoid form has an elongate basal ring with rounded corners. The two minor axis portals are distinctly smaller than the major axis portals. Although Dictyocha brevispina is still a mixed form-taxon involving numerous nomenclatural problems (see discussions of Dumitrica, 1973b), several distinctive members of the group, such as Dictyocha lingii Dumitrica, have been recently distinguished. Distinguishing paleoecologically or stratigraphically significant subgroups of $D$. brevispina is still possible, but an extreme range of intraspecific varition for this form, demonstrated by Deflandre (1950), will necessitate more thorough studies than are presently available.

\section{Dictyocha epiodon Ehrenberg}

(Plate 1, Figure 1)

Dictyocha epiodon Ehrenberg, 1844, p. 70, 79; Ehrenberg 1854, pl. 18, fig. 55 ; pl. 35A(11), fig. 1 ; pl. 35B(B,4), fig. 10.

Dictyocha fibula var. aculeata Lemmermann, 1901, p. 261, pl. 11, fig. $1,2$.

Dictyocha epiodon Ehrenberg, Bukry and Foster 1973, p. 826, pl. 2, fig. $7,8$.

Remarks: The canted apical bar may be unornamented or may have a spire. Specimens having vague or only partial development of the typical eight-sided basal ring are tabulated as compared species.

Dictyocha subarctios Ling (1970) appears to be a cold-water relative of $D$. epiodon having similar structural elements that are greatly modified to produce a distinctive new form (compare fig. 13 and 16 of pl. 18, Ling, 1970).

\section{Dictyocha fibula fibula Ehrenberg} (Plate 1, Figures 3, 4)

Dictyocha fibula Ehrenberg, 1839, p. 129; Ehrenberg 1840, pl. 4, fig. 16.

Remarks: Dumitrica (1973b) pointed out that there is considerable confusion as to what is and what is not Dictyocha fibula. Loeblich et al. (1968, pl. 9, fig. 7) illustrate Ehrenberg's first figured specimen and 
give its source as a seawater sample from Christiana, Norway. And indeed, the specimen's shape and distinctive asymmetric strut placement are typical of the dominant Holocene and Pleistocene Dictyocha of Leg 34. However, Dumitrica (1973b, p. 847) stated that a written communication from Sigurd Locker, who was studying Ehrenberg's types in Berlin, established a Miocene type locality in Oran which contained specimens of the form of Dictyocha fibula rhombica of Schulz (1928).

Because general usage (Deflandre, 1950; Mandra, 1968; Martini, 1971; Ling, 1972) of the name Dictyocha fibula has been for a third type of symmetric silicoflagellate that dominates the illustrations of $D$. fibula in Ehrenberg (1854), several possible solutions exist: (1) If the type of D. fibula is as described in Loeblich et al. (1968), then taxa in this report that are tabulated and illustrated as D. stapedia aspinosa and $D$. stapedia stapedia could be the original $D$. fibula and could be placed in synonomy with emendation for secondary structural variation. (2) If the type is as discussed by Dumitrica (1973b), then specimens tabulated in this report as $D$. brevispina should be assigned to $D$. fibula; the $D$. stapedia group could remain as cited; but, the form tabulated here as D. fibula fibula, based on Ehrenberg (1854), would require a different name, perhaps as a subspecies within the $D$. perlaevis group.

Eventual fixing of nomenclatural types should account for stratigraphic source, geographic range, general usage, evolutionary sequences, and possible ambiguity of original illustrations. In the taxonomic use of this report, fibuloid taxa such as Dictyocha perlaevis perlaevis and $D$. siapedia stapedia are most abundant in Quarternary assemblages in the eastern tropical Pacific, but $D$. fibula fibula is most prominent in Pliocene or Miocene assemblages (as at Site 77). The asperoid species D. brevispina is also most common in Pliocene or Miocene assemblages. When the form and geographic range of highand low-latitude phenotypes are better understood, taxonomy can be better stabilized.

\section{Dictyocha pentagona (Schulz)}

Dictyocha fibula var, pentagona Schulz, 1928, p. 255, fig. 41a, b. Dictyocha fibula Ehrenberg, Ling, 1970 (in part), p. 90, pl. 18, fig. 9, 10.

Dictyocha pentagona (Schulz) Bukry and Foster 1973, p. 827, pl. 3, fig. 10.

Remarks: Irregular specimens resembling Dictyocha pentagona have been produced by cultures of Dictyocha fibula s. ampl., but fossil forms are more symmetric (compare Ling, 1970, and Van Valkenburg and Norris, 1970). Theoretically, variants of Distephanus speculum pentagonus could also produce the form of Dictyocha pentagona.

\section{Dictyocha perlaevis delicata n. subsp.}

(Plate 1, Figures 5-10)

Description: Dictyocha perlaevis delicata has a large-lobed basal ring with rounded corners. Basal pikes may be located directly beneath the struts, or one set of pikes may be slightly offset. Spines are short, typically shorter than the struts. The apical bar is aligned with the major axis and equals one third or more of the basal-ring length. Both the apical bar and the struts are distinctly thinner than the basal ring.

Remarks: Dictyocha perlaevis delicata is distinguished from $D$. perlaevis perlaevis by the contrasting diameters of the apical structures and the basal ring. Whereas the diameters are equal in $D$. perlaevis perlaevis, the apical structures are only about one half the diameter of the basal ring structure in $D$. perlaevis delicata. Dictyocha fibula fibula is smaller and more elongate than $D$. perlaevis delicata and does not have a thin apical structure. Dictyocha lingii has an analogously thin apical structure, but is an asperoid form with a nearly round basal ring.

Two specimens of a cruxoid variant of $D$. perlaevis delicata were encountered in the present study.

Occurrence: Dictyocha perlaevis delicata is most common in the lower Quaternary at Sites 157 and 321 . Although it is missing in the upper Quaternary at Site 157 , it persisted at Site 321 in smaller numbers. Both $D$. perlaevis delicata and $D$. perlaevis perlaevis are tabulated together for Site 321 as $D$. perlaevis s. ampl.

A local zone based on the restricted range of Dictyocha perlaevis delicata at Site 157 is probably of limited geographic significance. By comparison, the tropical silicoflagellate assemblages of Site 77 (lat $0^{\circ} 29^{\prime} \mathrm{S}$, long $133^{\circ} 14^{\prime} \mathrm{W}$ ), also in the eastern tropical Pacific but outside the effects of the Humboldt Current, have a different species composition. The upper Pliocene to lower Quaternary at Site 77 lacks $D$. perlaevis delicata, D. stapedia stapedia, and Distephanus boliviensis boliviensis. Instead, the upper Pliocene is characterized by Dictyocha fibula fibula, D. perlaevis perlaevis, and D. speculum speculum. Therefore, coeval assemblages, even from similar latitudes, reflect differences in water-mass characteristics that limit wide stratigraphic use of taxa such as $D$. perlaevis delicata.

Size: Basal-ring major axis 35-50 $\mu \mathrm{m}$; holotype $45 \mu \mathrm{m}$.

Holotype: USNM 218626 (Plate 1, Figures 5, 6).

Paratypes: USNM 218627 to 218630

Type locality: DSDP 321-3-3, 50-52 cm (15 m), southeastern Pacific Ocean.

\section{Dictyocha sp. cf. D. perlaevis delicata}

$$
\text { (Plate 2, Figures 1-3) }
$$

Remarks: This form differs from Dictyocha perlaevis delicata s. str. by having a shorter apical bar that is only slightly thinner than the basal ring, by having longer spines, more equant major and minor axis, and more angular corners along the minor axis. The combined effect of these changes in proportion produces a distinctive form. Dictyocha sp. cf. D. perlaevis delicata is most common at Sites 320 and 321 in the upper Quaternary Dictyocha epiodon Zone. The taxonomic distinction and paleoecological significance of this form was first recognized by Poelchau (1974) as part of an environmental analysis of Holocene silicoflagellates from the Pacific. Poelchau noted this form was most common in areas of warm equatorial waters. Its occurrence at Sites 320 and 321 supports a warm-water environment for this taxon.

\section{Dictyocha perlaevis perlaevis Frenguelli (Plate 2, Figures 4, 5)}

Dictyocha perlaevis Frenguelli, 1951, p. 279, fig. 4b-c. Dictyocha fibula perlaevis (Frenguelli), Bukry, 1975a, pl. 4, fig. 4, 8.

Remarks: Dictyocha perlaevis perlaevis is a large species of fibuloid form that is distinguished from the similar form $D$. perlaevis delicata by its more robust apical structures. Forms such as Dictyocha perlaevis perlaevis, with a scalloped outline caused by the rounded, bowed-out corners, are most common in low-latitude assemblages; they are rare among fibuloid forms from high latitude.

\section{Dictyocha pulchella Bukry}

Dictyocha rhombica (Schulz), Martini, 1971 (in part), p. 1698, pl. 1, fig. 8 (not 9-10).

Dictyocha sp., Ling, 1972 (in part), p. 163, pl. 26, fig. 4-6 (not 7-8). Dictyocha pulchella Bukry, 1975a, pl. 4, fig. 1-3.

\section{Dictyocha stapedia aspinosa n. subsp. \\ (Plate 2, Figures 6-9)}

Description: $D$. stapedia aspinosa has a rounded rhombic to slightly lobed, small basal ring with four basal pikes. Like D. stapedia stapedia from which it differs by lacking any spire, $D$. stapedia aspinosa shows variation in spine length and has slight asymmetry in strut location.

Remarks: Small size, rounded rhombic basal ring, and slightly asymmetric strut location distinguish Dictyocha stapedia aspinosa from all fibuloid forms but $D$. stapedia stapedia. The absence of a spire is used to distinguish D. stapedia aspinosa.

Occurrence: Dictyocha stapedia aspinosa is especially common in two late Quaternary samples from Sites 157 and 321 . These restricted abundance peaks suggest that $D$. stapedia aspinosa is an ecologic variant of $D$. stapedia stapedia and that their ratios might provide a paleoecologic gauge. Its distribution is unknown beyond the Nazca plate.

Size: Basal-ring major axis $20-45 \mu \mathrm{m}$; holotype $40 \mu \mathrm{m}$.

Holotype: USNM 218631 (Plate 2, Figures 7, 8).

Paratypes: USNM 218632 and 218633.

Type locality: DSDP $321-2-1,80-82 \mathrm{~cm}(3 \mathrm{~m})$, southeastern Pacific Ocean.

\section{Dictyocha stapedia stapedia Haeckel}

$$
\text { (Plate 3, Figures 1-7) }
$$

Dictyocha stapedia Haeckel, 1887, p. 1561, pl. 101, fig. 10-12. Dictyocha rhombus Haeckel, 1887, p. 1562; Lemmermann 1901, pl. 11, fig. 3.

Remarks: There are several possible names that could be applied to the forms here called Dictyocha stapedia stapedia. No matter what 
name is assigned, it is a dominant species in Quaternary assemblages at Sites 320 and 321. Although the name Dictyocha messanensis Haeckel has been used previously (Ling, 1972; Poelchau, 1974), the name $D$. stapedia stapedia is preferred for the following reasons. Although the original drawings of both taxa are stylized, the extremely short apical bar and lack of basal pikes make $D$. messanensis a very aberrant form in terms of Leg 34 assemblages. However, the range of skeletons of $D$. stapedia Haeckel (1887) shows a more typically sized apical bar and distinctive basal pikes which were used by Haeckel to distinguish the two species. D. stapedia was described as cosmopolitan in all warmer seas. Haeckel's own distinction based on structural differences and geographic occurrence are considered the most reasonable basis for the choice of $D$. stapedia over $D$. messanensis.

The illustration of $D$. rhombus has structural elements similar to $D$. stapedia and in terms of the less lobed basal ring is more comparable to Quaternary assemblages of Leg 34 , but its basal ring form falls within the range shown for $D$. stapedia, and its basal pikes are probably overly stylized in their location.

Although D. stapedia stapedia is used as nomenclatural base for this form, some additional description is needed. The strut placement on specimens with lobed and simply bowed basal rings is asymmetric in a clockwise sense, if the specimens are seen in apical view. The spire on the apical bar is usually central but can be offset to one end of the apical bar. The apical bar may be slightly misaligned with the major axis, suggesting a relation between $D$. stapedia stapedia and $D$. epiodon.

Although parallel to each other, the opposed spines may be canted from the major axis, causing a slightly rotated appearance (see Plate 3, Figure 6).

\section{Dictyocha? sp. (naviculopsoid)}

(Plate 3, Figure 8)

Dictyocha navicula (Ehrenberg), Bukry and Foster, 1973, p. 827, pl. 3, fig. 6-8.

Remarks: The occurrence of naviculopsoid silicoflagellates, resembling Naviculopsis quadrata, in the upper Miocene at Sites 157, 303 , and 304 raises a fundamental question in silicoflagellate stratigraphy and taxonomy. Whereas the specimens at these Pacific DSDP sites have the morphologic character of the genus Naviculopsis, the basic stratigraphic range of the genus is Paleocene to lower Miocene. Rare naviculopsoid specimens from the middle or upper Miocene have been traced through intermediate forms to Dictyocha brevispina of this report (Deflandre, 1950; Ling, 1972).

As more intervening stratigraphic sections are documented, the true affinities of such forms may be determined. Until sufficient data are available, suspicious taxonomic situations may be reported by informal morphologic terms such as: asperoid-resembling the Dictyocha aspera group apical bar pattern; cruxoid-resembling the Distephanus crux group apical ring pattern; deflandroid-resembling the Dictyocha deflandrei group apical plate pattern; fibuloid-resembling the Dictyocha fibula group apical bar pattern; medusoid-resembling the Dictyocha medusa central strut junction; mesocenoid-resembling the basal ring dominance of genus Mesocena but possessing some apical vestiges; and naviculopsoid-resembling the basal ring and apical structures of genus Naviculopsis.

\section{Genus DISTEPHANUS Stöhr, 1880}

Distephanus boliviensis boliviensis (Frenguelli)

Dictyocha boliviensis Frenguelli, 1940, p. 44, fig. 4.

Distephanus boliviensis (Frenguelli) Bukry and Foster, 1973, p. 827, pl. 4, fig. 1-3.

Remarks: All specimens assigned to this taxon in this report have large robust apical rings. No specimens occur of Distephanus boliviensis frugalis, a high-latitude form with small apical rings (Bukry, 1975a).

\section{Distephanus boliviensis major (Frenguelli)}

Dictyocha boliviensis Frenguelli, 1940 (in part), p. 44, fig. 4b-d. Dictyocha boliviensis var. major Frenguelli, 1951, p. 277, fig. 3a-3c. Cannopilus major (Frenguelli) Bukry and Foster, 1973, p. 826, pl. 1, fig. 4-7; pl. 7, fig. 4 .

Distephanus boliviensis major (Frenguelli) Bukry, 1975a.

\section{Distephanus crux (Ehrenberg)}

Dictyocha crux Ehrenberg, 1840, p. 207; Ehrenberg, 1854, pl. 18, fig. 56; pl. 20 (1), fig. 46; pl. 33 (15), fig. 9; pl. 33 (16), fig. 9; pl. 33 (17), fig. 5.

Remarks: The small numbers of Distephanus crux in the samples studied suggests possible reworking or abnormal phenotypic developments from other taxa. Some cruxoid forms can be directly attributed to other species such as Dictyocha perlaevis (Plate 1, Figure 7) or Dictyocha epiodon (Bukry and Foster, 1973, pl. 4, fig. 5) because of distinctive features other than quadrate geometry. Because the main populations of Distephanus crux around the world are Oligocene and Miocene in age, the phylogenetic significance of sporadic Pliocene and Pleistocene occurrences is not clear, and the species is not used in stratigraphic determinations for Leg 34.

\section{Distephanus speculum elongatus Bukry}

Distephanus speculum elongatus Bukry, 1975a, pl. 2, fig. 8, 9; pl. 3, fig. $1-3$.

Remarks: This subspecies of the Distephanus speculum group has an elongate apical ring and is considered a cool-water form, composing up to $26 \%$ of the $D$. speculum group at Site 278 (lat $57^{\circ} \mathrm{S}$, long $160^{\circ} \mathrm{E}$ ).

\section{Distephanus speculum speculum (Ehrenberg)}

Dictyocha speculum Ehrenberg, 1839, p. 150; Ehrenberg, 1854, pl. 18, fig. 57 ; pl. 19 , fig. 41 ; pl. 21, fig. 44 ; pl. 22, fig. 47 .

Dictyocha speculum Ehrenberg, Martini, 1971, p. 1698, pl. 1, fig. 13, 14.

Distephanus speculum (Ehrenberg), Bukry and Foster, 1973, p. 828, pl. 5 , fig. 8.

\section{Genus MESOCENA Ehrenberg, 1843}

\section{Mesocena circulus (Ehrenberg)}

Dictyocha (Mesocena) circulus Ehrenberg, 1840, p. 208; Ehrenberg, 1854 , p. 19 , fig. 44.

Mesocena circulus (Ehrenberg), Bukry, 1975b, pl. 6, fig. 1, 2.

\section{Mesocena elliptica (Ehrenberg)}

(Plate 3, Figure 11)

Dictyocha (Mesocena) elliptica Ehrenberg, 1840, p. 208; Ehrenberg, 1854, pl. 20 (I), fig. 44.

Mesocena elliptica (Ehrenberg), Bukry and Foster, 1973, p. 828, pl. 6, figs. 2-4.

\section{Genus OCTACTIS Schiller, 1925 \\ Octactis pulchra Schiller \\ (Plate 3, Figure 9, 10)}

Octactis pulchra Schiller, 1926, p. 67, fig. c.

Distephanus octagonus (Ehrenberg), Dumitrica, 1973a, p. 908, pl. 12, fig. 15-19.

Octactis pulchra Schiller, Bukry and Foster, 1973, p. 829, pl. 6, fig. 11, 12.

Remarks: The delicate apical ring structure and absence of basal pikes serve to distinguish Octactis pulchra from species of Distephanus (see Poelchau, 1974).

\section{REFERENCES}

Bachmann, A. and Keck, A., 1969. Die Oberflächenstruktur der Silicoflagellaten: Mikrokosmos, v. 7, p. 204-207.

Bramlette, M.N. and Wilcoxon, J.A., 1967. Middle Tertiary calcareous nannoplankton of the Cipero section, Trinidad, W.I.: Tulane Stud. geol., v. 5, p. 93-131.

Bukry, D., 1973. Coccolith stratigraphy, eastern equatorial Pacific, Leg 16 Deep Sea Drilling Project. In van Andel, Tj.H., Heath, G.R., et al., Initial Reports of the Deep Sea Drilling Project, Volume 16: Washington (U.S. Government Printing Office), p. 653-711.

, 1974. Coccolith and silicoflagellate stratigraphy, eastern Indian Ocean, Deep Sea Drilling Project Leg 22. In 
von der Borch, C.C., Initial Reports of the Deep Sea Drilling Project, Volume 22: Washington (U.S. Government Printing Office), p. 601-607.

1975a. Coccolith and silicoflagellate startigraphy, northwestern Pacific Ocean, Deep Sea Drilling Project Leg 32. In Larson, R.L., Moberly, R., et al., Initial Reports of the Deep Sea Drilling Project, Volume 32: Washington (U.S. Government Printing Office), p. 1975b. Silicoflagellate and coccolith stratigraphy, Deep Sea Drilling Project Leg 29. In Kennett, J.P., Houtz, R.E., et al., Initial Reports of the Deep Sea Drilling Project, Volume 29: Washington (U.S. Goverment Printing Office), p. 845-872.

Bukry, D. and Foster, J.H., 1973. Silicoflagellate and diatom stratigraphy, Leg 16, Deep Sea Drilling Project. In van Andel, Tj.H., Heath, G.R., et al., Initial Reports of the Deep Sea Drilling Project, Volume 16: Washington (U.S. Government Printing Office), p. 815-871.

1974. Silicoflagellate zonation of Upper Cretaceous to lower Miocene deep-sea sediment: U.S. Geol. Surv. J. Res., v. 2, p. 303-310.

Burckle, L.H., 1972. Late Cenozoic planktonic diatom zones from the Eastern Equatorial Pacific: Nova Hedwig. Beihefte, v. 39, p. 217-246.

Ciesielski, P.F. and Weaver, F.M., 1974. Early Pliocene temperature changes in the Antarctic seas: Geology, v. 2, p. 511-515.

Deflandre, G., 1950. Contribution a l'étude des silicoflagellidés actuels et fossiles: Microscopie, v. 2, p. 72-108, 117142 , and 191-210.

Donahue, J.G., 1970. Pleistocene diatoms as climatic indicators in North Pacific sediments: Geol. Soc. Am. Mem. 126, p. 121-138.

Dumitrica, P., 1973a. Miocene and Quaternary silicoflagellates in sediments from the Mediterranean Sea. In Ryan, W.B.F., Hsu, K.J., et al., Initial Reports of the Deep Sea Drilling Project, Volume 13: Washington (U.S. Government Printing Office), p. 902-933.

1973b. Paleocene, late Oligocene and postOligocene silicoflagellates in southwestern Pacific sediments cored on DSDP Leg 21. In Burns, R.E., Andrews, J.E., et al., Initial Reports on the Deep Sea Drilling Project, Volume 21: Washington (U.S. Government Printing Office), p. 837-883.

Ehrenberg, C.G., 1839. Uber die Bildung der Kreidefelsen und des Kreidemergels durch unsichtbare Organismen: K. Akad. Wiss. Berlin Abh., Jahrg. 1838 (1840, separate 1839), p. $59-148$

1840a. Uber noch jetzt zahlreich lebende Thierarten der Kreidebildung und den Organisms der Polythalamien: Akad. Wiss. Berlin Abh., Jahrg. 1839, p. 81-174.

1840b. 274 Blätter von ihm selbst ausgeführter Zeichnungen von ebenso vielen Arten: K. Preuss. Akad. Wiss. Berlin Ber., Jahrg. 1840, p. 197-219 (Nov.).

1844. Mittheilung über zwei neue Lager von Gebirgsmassen aus Infusorien als Meeres-Absatz in NordAmerika und eine Vergleichung derselben mit den organischen Kreide-Gebilden in Europa und Afrika: K. Preuss. Akad. Wiss. Berlin Ber., Jahrg. 1844, p. 57-97. 374. 1854. Mikrogeologie: Leipzig (Leopold Voss), p. 1-

Frenguelli, J., 1940. Consideraciones sobre los sílicoflagelados fósiles: Mus. La Plata Rev., Paleontol., v. 2, p. 37-112.

1951. Silicoflagelados del Trípoli de Mejillones (Chile): Physis [Buenos Aires], v. 20, p. 272-284.

Gemeinhardt, K., 1930. Silicoflagellatae. In Rabenhorst, L. (Ed.), Kryptogamen-Flora von Deutschland, Osterreich und der Schweiz: Leipzig (Akad. Verlagsgesell.), v. 10, p. 187.
Glezer, Z.I., 1966. Silicoflagellatophyceae. In Gollerbakh, M.M. (Ed.), Cryptogamic plants of the U.S.S.R.: Akad. Nauk SSSR, V.A. Komarova Bot. Inst. (Translated from Russian by Israel Program for Scientific Translations Ltd., Jerusalem, 1970), v. 7, p. 1-363.

Haeckel, E.H.P.A., 1887. Cannorrhaphida: Challenger Rept., v. 18 , p. $1546-1569$.

Jendrzejewski, J.P. and Zarillo, G.A., 1971. Late Pleistocene paleotemperatures: silicoflagellate and foraminiferal frequency changes in a deep-sea core: U.S. Antarctic J., v. 6, p. 178-179.

Jerković, L., 1969. Les nouvelles recherches de la superficie du squelette des silicoflagellidés: Univ. Sarajevu Biol. Inst. Godisnjaka, v. 22, p. 129-176.

1971. Tendances évolutives de l'ultrastructure superficielle du squelette des silicoflagellidés (CretacéRécent): 2nd Plankt. Conf. Proc., p. 659-662.

Lemmermann, E., 1901. Silicoflagellatae: Deutsche Bot. Gesell. Ber., v. 19, p. 247-271.

Ling, H.Y., 1970. Silicoflagellates from central North Pacific core sediments: Am. Paleontol. Bull., v. 58, p. 85-129.

1972. Upper Cretaceous and Cenozoic silicoflagellates and ebridians: Am. Paleontol. Bull., v. 62, p. 135-229.

Loeblich, A.R., 3d, Loeblich, L.A., Tappan, H., and Loeblich, A.R., Jr., 1968. Annoted index of fossil and recent silicoflagellates and ebridians with descriptions and illustrations of validly proposed taxa: Geol. Soc. Am. Mem. $106,319 \mathrm{p}$

Mandra, Y.T., 1968. Silicoflagellates from the Cretaceous, Eocene, and Miocene of California, U.S.A.: California Acad. Sci. Proc., v. 36, p. 231-277.

1969. Silicoflagellates: A new tool for the study of Antarctic Tertiary climates: U.S. Antarctic J., v. 4, p. 172174.

Mandra, Y.T. and Mandra, H., 1972. Paleoecology and taxonomy of silicoflagellates from an upper Miocene diatomite near San Felipe, Baja California, Mexico: California Acad. Sci. Occasional Paper 99, p. 1-35.

Martini, E., 1971. Neogene silicoflagellates from the equatorial Pacific. In Winterer, E.L., Riedel, W.R., et al., Initial Reports of the Deep Sea Drilling Project, Volume 7: p. $1695-1708$.

McPherson, L.M. and Ling, H.Y., 1973. Surface microstructure of selected silicoflagellates: Micropaleontology, v. 19, p. 475-480.

Poelchau, H.S., 1974. Holocene silicoflagellates of the North Pacific: their distribution and use for paleotemperature determination: Ph. D. dissertation, Univ. Calif., San Diego, p. $1-165$.

Schiller, J., 1926. Die planktontischen Vegetation des adriatischen Meers.: B. Chrysomonadina, Heterokontae, Cryptomonadina, Eugleninae, Volvocales. 1. Systematischer Teil: Arch. Protistenk, v. 53, p. 59-123.

Schulz, P., 1928. Beiträge zur Kennınis fossiler und rezenter Silicoflagellaten: Bot. Archiv, v. 21, p. 15-292.

Tynan, E.J., 1957. Silicoflagellates of the Calvert formation (Miocene) of Maryland: Microplaeontology, v. 3, p. 127136.

Van Valkenburg, S.D. and Norris, R.E., 1970. The growth and morphology of the silicoflagellate Dictyocha fibula Ehrenberg in culture: J. Phycol., v. 6, p. 48-54.

Wornardt, W.W., Jr., 1971. Eocene, Miocene and Pliocene marine diatoms and silicoflagellates studied with the scanning electron microscope: 2nd Plankt. Conf. Proc., p. 12771300 . 



\section{PLATE 1}

Silicoflagellates from DSDP Legs 34 and 16 Magnification $800 \times$; scale bar equals $10 \mu \mathrm{m}$.

Figure 1 Dictyocha epiodon Ehrenberg. Sample 320A-1A-2, $44-45 \mathrm{~cm}(2 \mathrm{~m})$.

Figure 2 Dictyocha sp. cf. D. epiodon Ehrenberg. Sample 157-1-5, 8-10 cm (16 m).

Figures 3, 4 Dictyocha fibula fibula Ehrenberg.

3. Sample 157-9-3, 8-10 cm (84 m).

4. Sample $157-11-3,24-26 \mathrm{~cm}(102 \mathrm{~m})$.

Figures 5-10 Dictyocha perlaevis delicata $n$. subsp.

5, 6. Holotype, USNM 218626, Sample 321-3-3, $50-52 \mathrm{~cm}(15 \mathrm{~m})$, apical and basal focus.

7. USNM 218627, Sample 157-11-3, 24-26 cm $(102 \mathrm{~m})$, cruxoid variant.

8. USNM 218628, Sample 321-3-3, 50-52 cm (15 $\mathrm{m})$.

9. USNM 218629, Sample 157-9-3, 8-10 cm (84 $\mathrm{m})$.

10. USNM 218630, Sample 157-8-3, 8-10 cm (76 $\mathrm{m})$. 

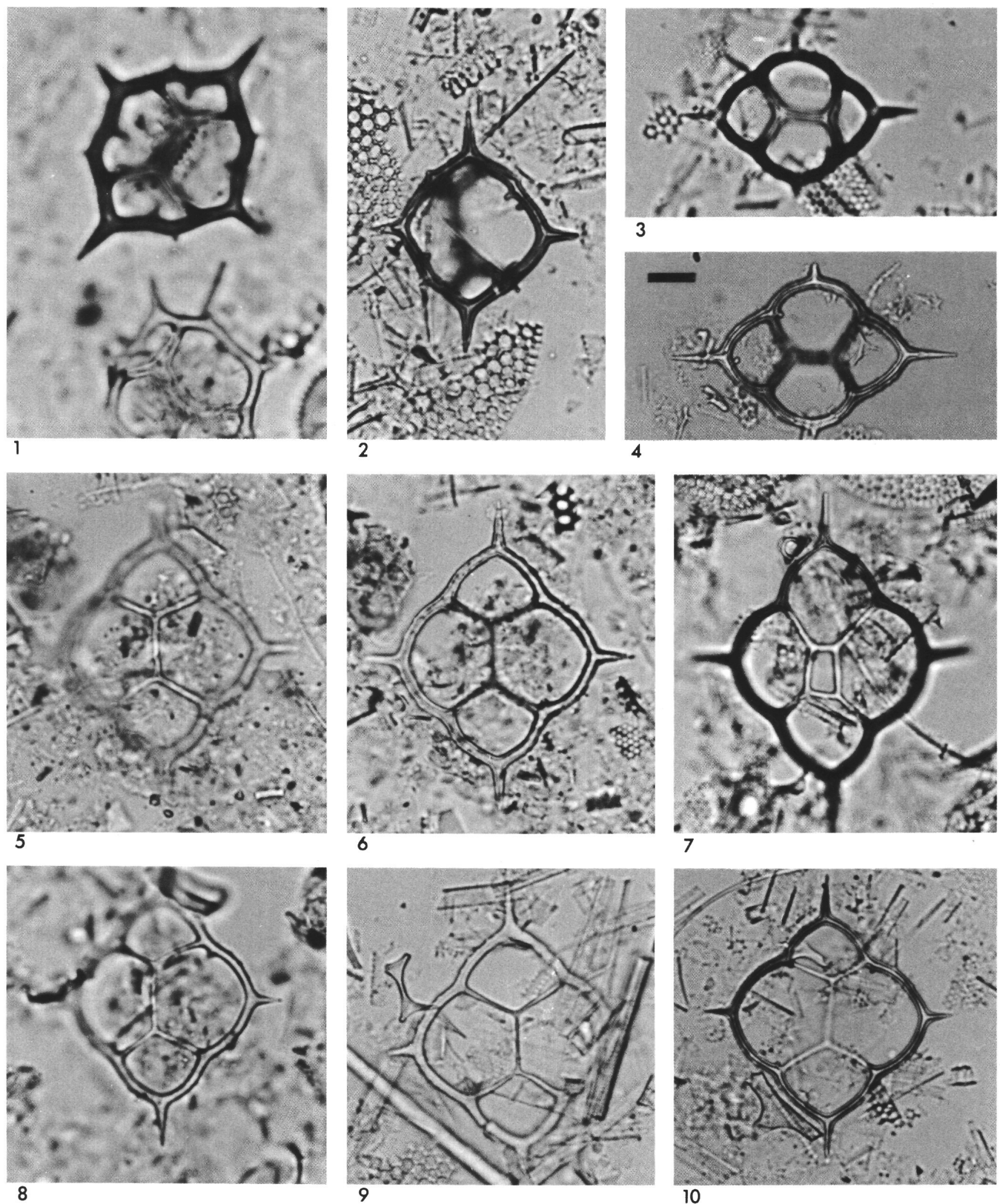


\section{PLATE 2}

Silicoflagellates from DSDP Legs 34 and 16 Magnification $800 \times$; scale bar equals $10 \mu \mathrm{m}$.

Figures 1-3 Dictyocha sp. cf. D. perlaevis delicata n. subsp.

1, 2. Sample 321-2-1, 80-82 cm (3 m).

3. Sample 157-11-3, 24-26 cm (102 m).

Figures 4, 5 Dictyocha perlaevis perlaevis Frenguelli.

4. Sample 157-9-3, 8-10 cm (84 m).

5. Sample 157-11-3, 24-26 cm (102 m), distorted.

Figures 6-9 Dictyocha stapedia aspinosa n. subsp.

6. USNM 218632, Sample 157-2-3, 8-10 cm (22 $\mathrm{m})$.

7, 8. Holotype, USNM 218631, Sample 321-2-1, $80-82 \mathrm{~cm}(3 \mathrm{~m})$, basal and apical focus.

9. USNM 218633, Sample 157-4-5, 8-10 cm (43 $\mathrm{m})$. 


\section{PLATE 2}

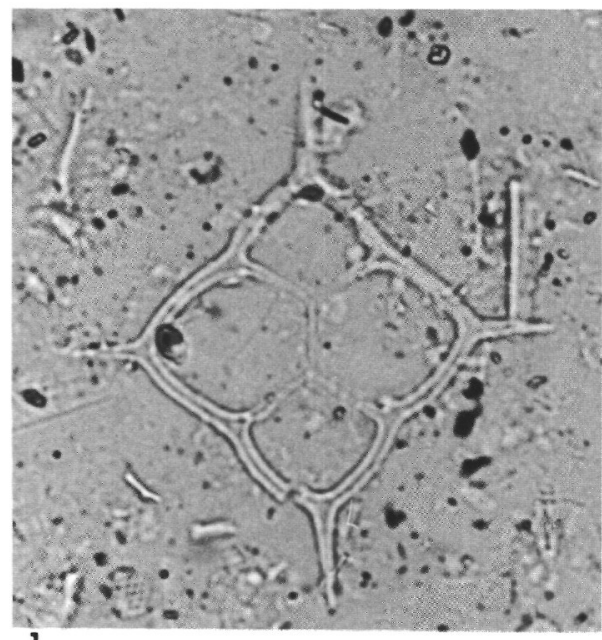
1

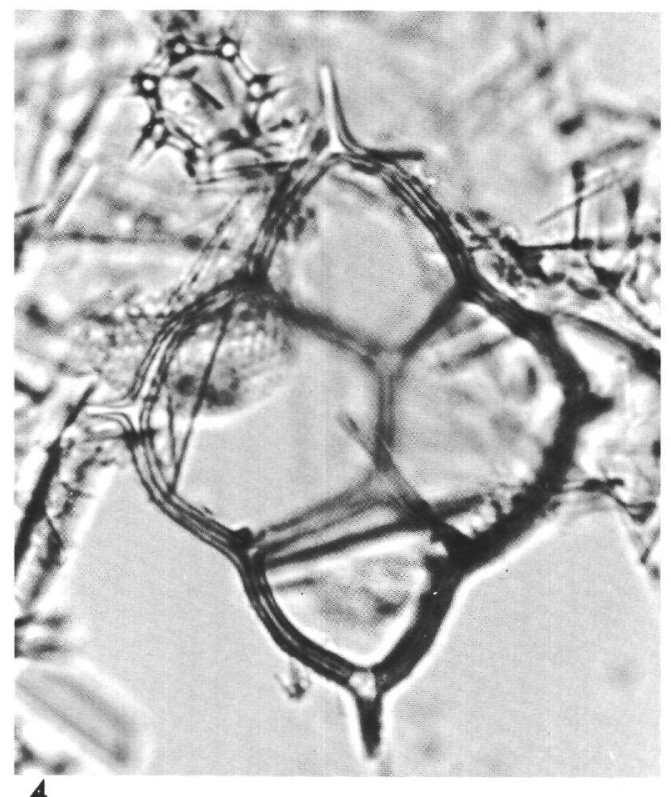

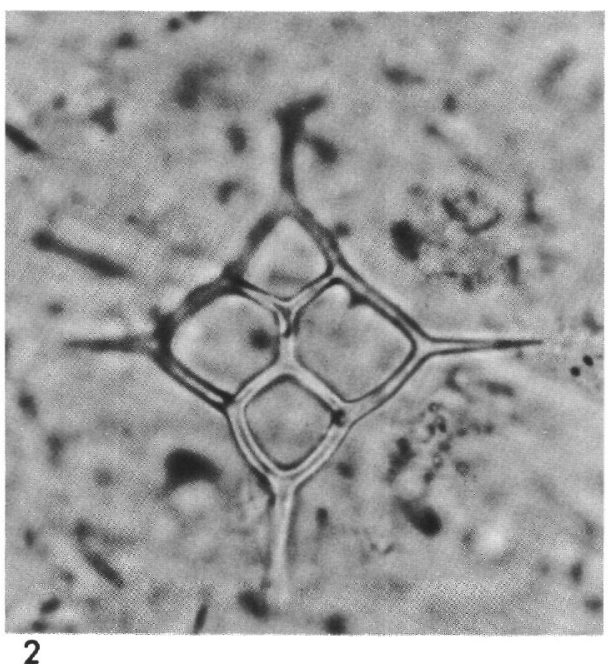
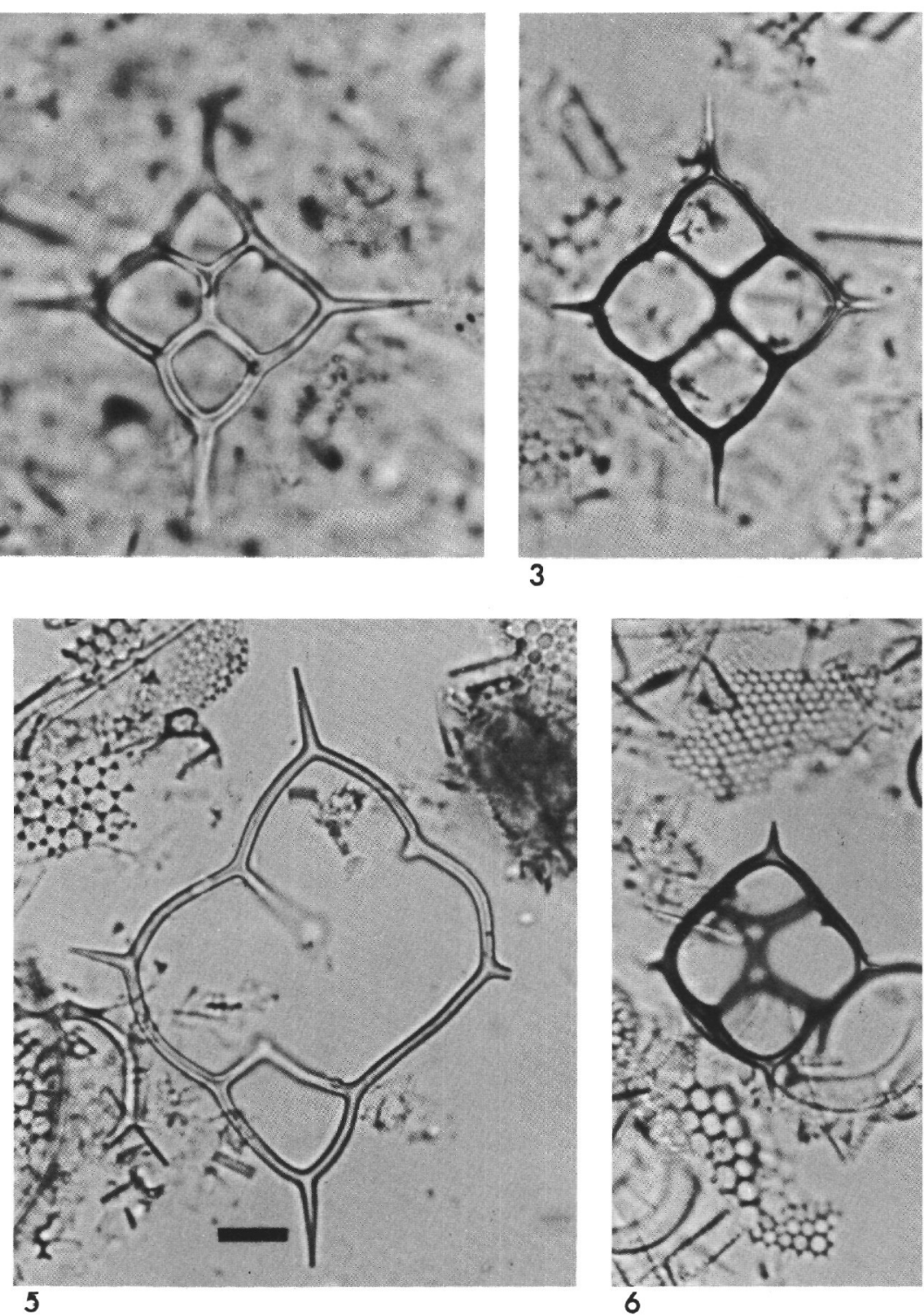
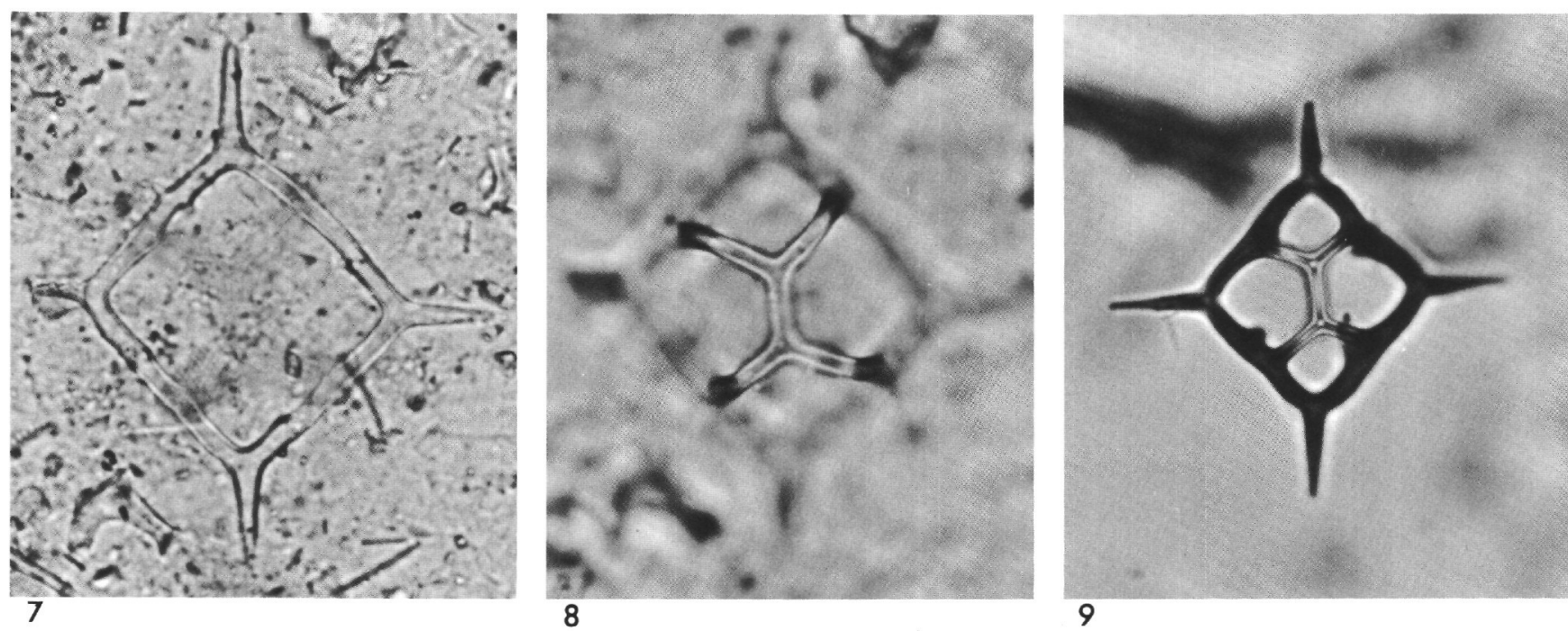


\section{PLATE 3}

Silicoflagellates from DSDP Leg 34, DSDP Leg 16, and California

Figures 11, 12 Mesocena with slightly reticulate surface.

Magnification $800 \times$; scale bar equals $10 \mu \mathrm{m}$.

Figures 1-7 Dictyocha stapedia stapedia Haeckel.

1, 2. Sample $321-3-5,89-91 \mathrm{~cm}(18 \mathrm{~m})$, basal and apical focus.

3, 4. Sample 320A-1A-2, $44-45 \mathrm{~cm}(2 \mathrm{~m})$, mid and apical focus.

5. Sample $320-1-0,40-41 \mathrm{~cm}(6 \mathrm{~m})$, spire focus, tilted specimen.

6, 7. Sample $320 \mathrm{~A}-1 \mathrm{~A}-2,44-45 \mathrm{~cm}(2 \mathrm{~m})$, basal and spire focus.

Figure 8 Dictyocha? sp. (naviculopsoid). Sample 157-11-3, 24-26 cm (102 m).

Figures 9,10 Octactis pulchra Schiller.

9. Sample $157-7-3,8-10 \mathrm{~cm}(66 \mathrm{~m})$, apical focus.

10. Sample $157-8-3,8-10 \mathrm{~cm}(76 \mathrm{~m})$, basal focus.

Figure $11 \quad$ Mesocena elliptica (Ehrenberg).

Sample 321-2-3, 82-84 cm (5 m).

Figure 12 "Mesocena polymorpha Lemmermann"

Sample LJ75011701, Puente Formation, Baldwin

Park, California. 
PLATE 3
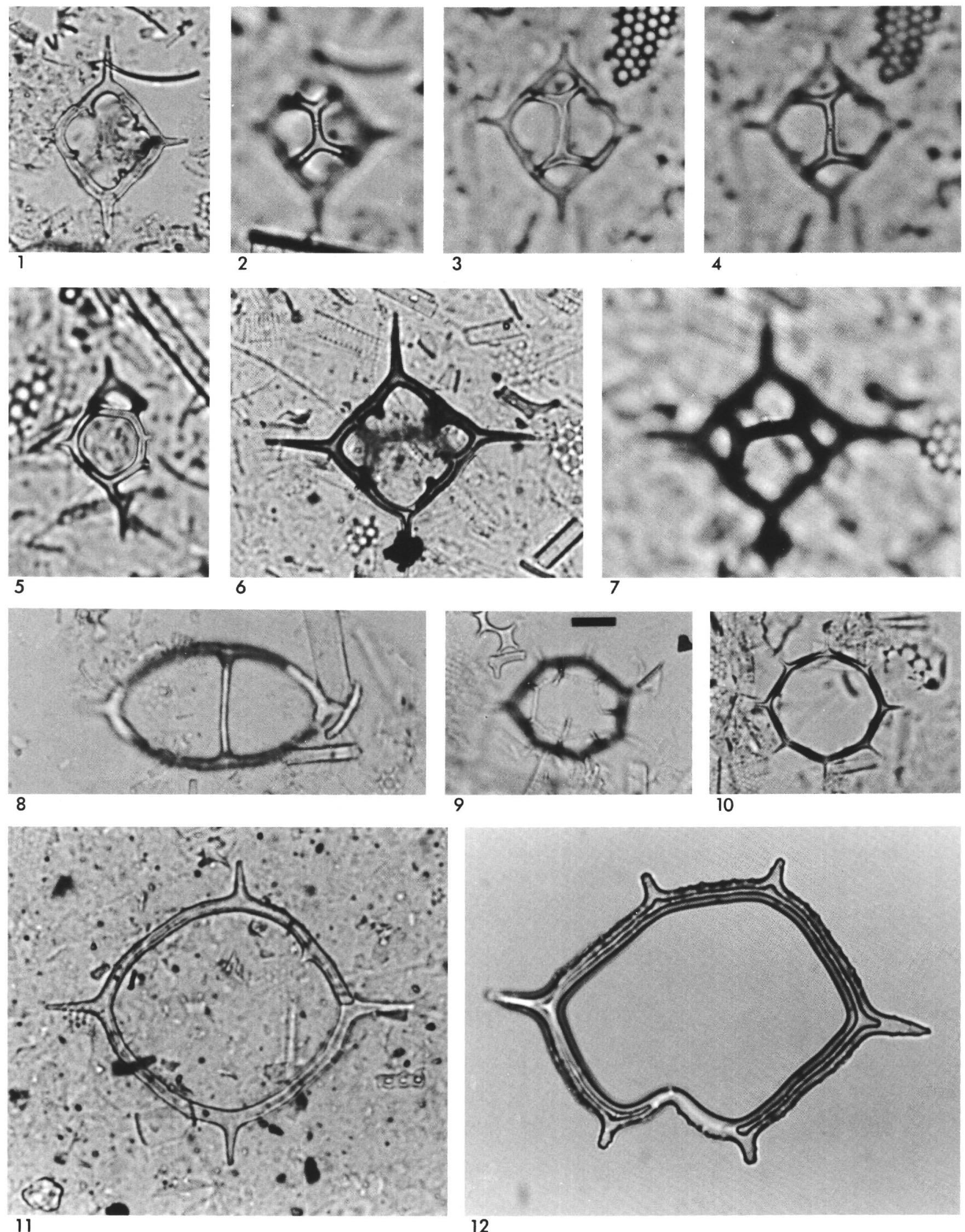


\section{PLATE 4}

Silicoflagellate surface textures of specimens of Mesocena from California and Hannaites from Kamischev, USSR. Special slide preparations by Herman Adler, El Cajon, California.

Figures $1-5$, magnification $800 \times$, scale bar equals $10 \mu \mathrm{m}$.

Figures 6, 7, magnification $3000 \times$, scale bar equals $5 \mu \mathrm{m}$.

Figures 1-4 "Mesocena polymorpha Lemmermann."

Sample LJ75011701, Puente Formation, Baldwin Park, California. Miocene.

1. Reticulate.

2, 3. Noded.

4. Reticulate and piked.

Figures 5-7 Hannaites sp.

Sample LJ72012801, Kamischev, USSR. Eocene.

5. Reticulation most pronounced on bulbs.

6. Bulb enlargement, mid focus.

7. Bulb enlargement, surface focus of reticulate pattern. 
PLATE 4

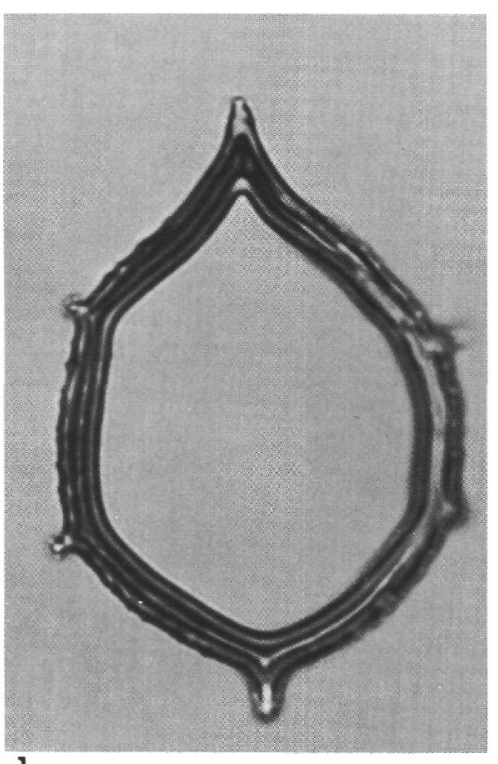

1

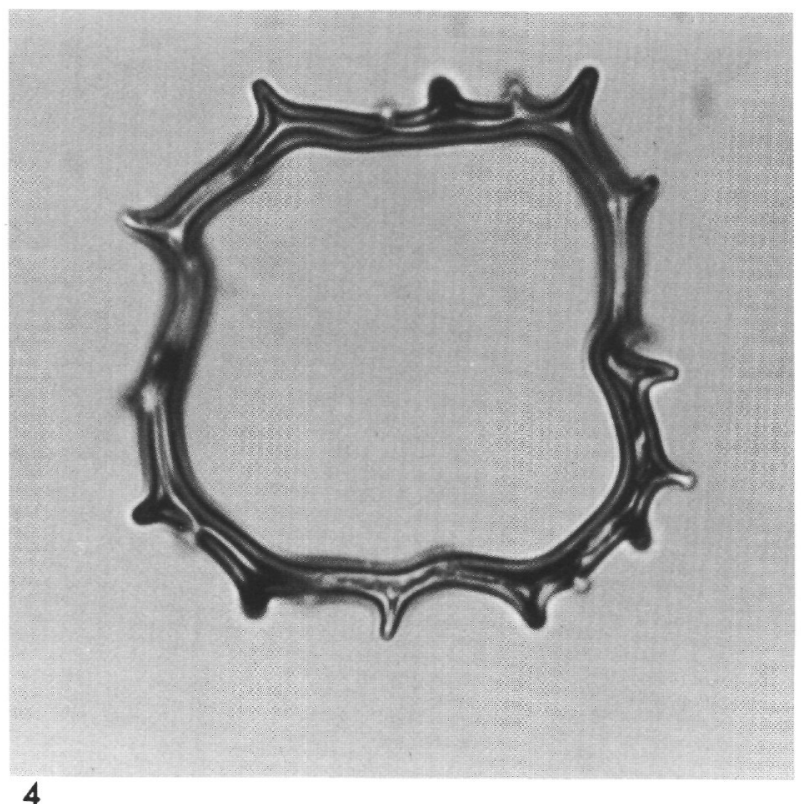

4

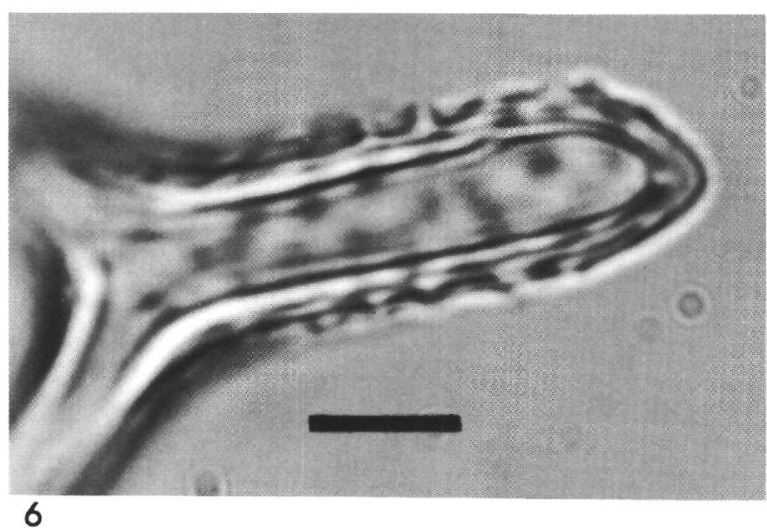

2
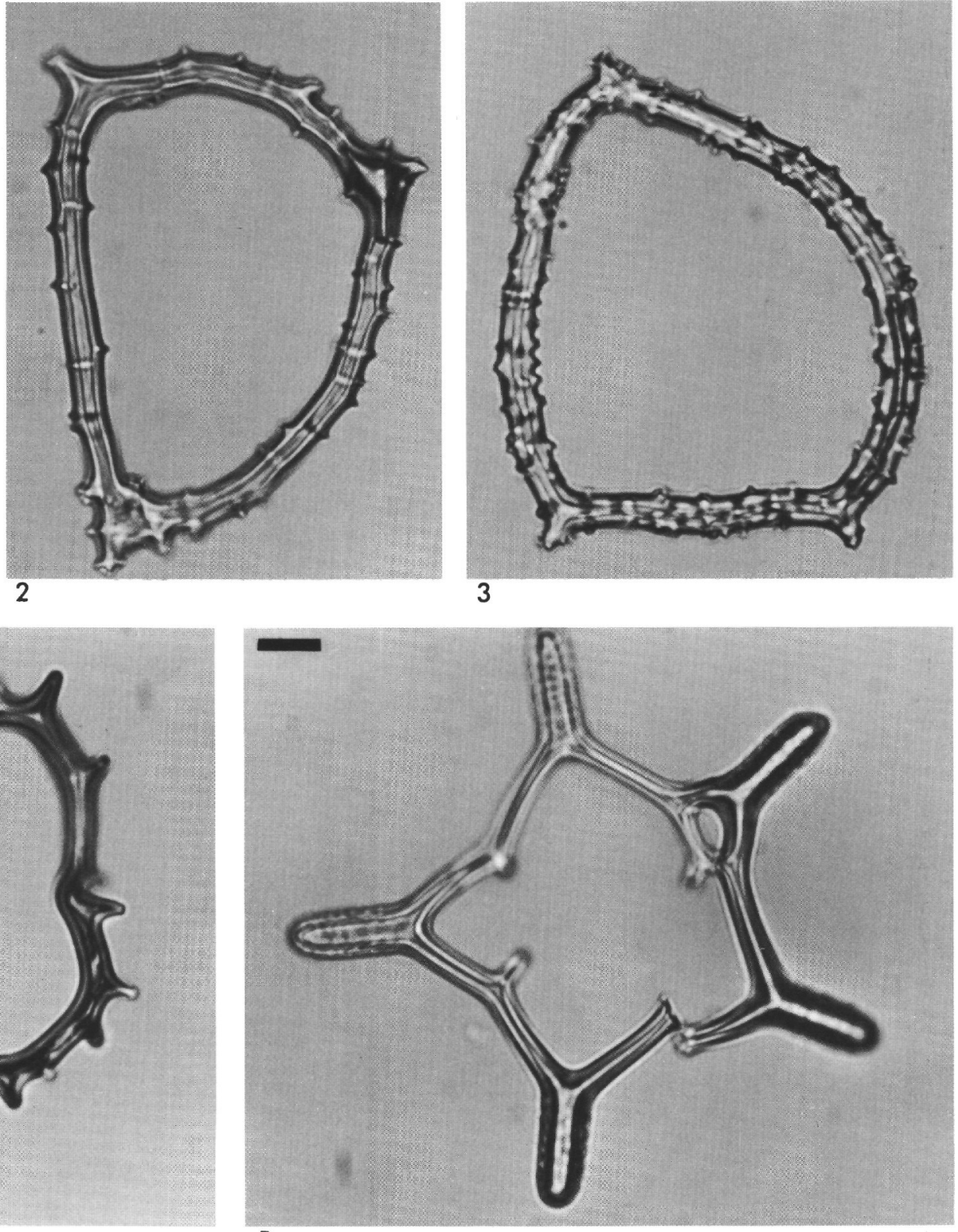

5

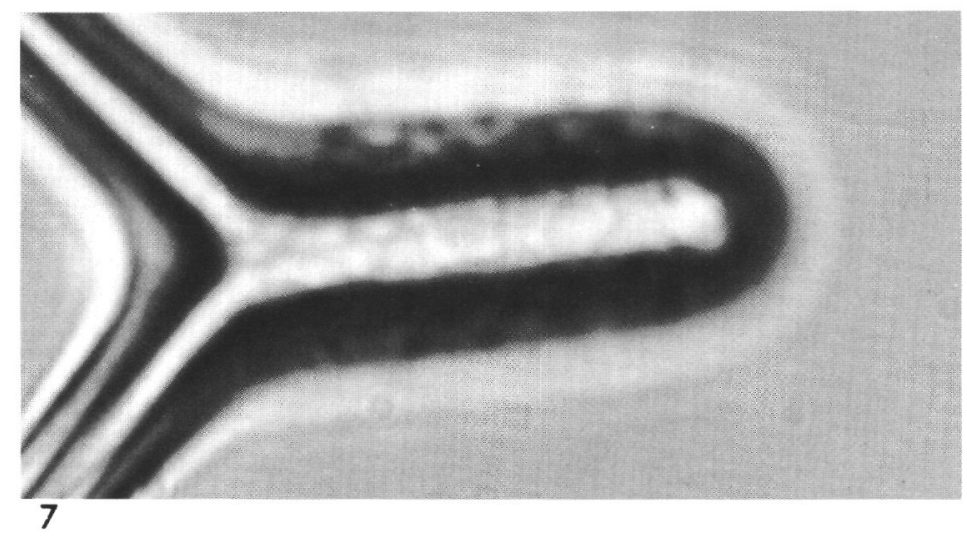

